ISSN: 0213-2060

DOI: https://doi.org/10.14201/shhme2020382942

\title{
ELITISM AND STATUS: REASSESSING SETTLEMENT HIERARCHY IN EARLY MEDIEVAL ENGLAND ${ }^{1}$
}

\author{
Elitismo y estatus: reevaluando la jerarquía de los asentamientos en la Inglaterra \\ altomedieval \\ Hana LEWIS \\ Heritage NSW. Department of Premier and Cabinet. 6/10 Valentine Avenue, Parramatta, NSW, Australia 2150. \\ C.e.: hana.lewis@uclmail.net
}

Recibido: 2020-06-16

Revisado: 2020-09-28

Aceptado: $2020-10-26$

ABSTRACT: The complexities of identifying and understanding settlement hierarchy in early medieval England (c. $5^{\text {th }}-11^{\text {th }}$ centuries) is the focus of much debate. Within this field of enquiry, settlement arrangements, architecture, landholding patterns and material culture are commonly used in the identification of a range of settlement types. These include royal complexes, monastic institutions, towns and trading/production sites such as emporia. This same evidence is also used to interpret the status and role of these sites in early medieval England. This paper advances the current understanding of settlement hierarchy through an assessment of rural settlements and their material culture. These settlements have received comparatively less scholarly attention than higher profile early medieval sites such as elite, ecclesiastical and urban centres, yet represent a rich source of information. Through analysis of material culture as evidence for the consumption, economic and social functions which characterise rural settlements, a picture of what were inherently complex communities is presented. The findings further support the need to reassess settlement hierarchy in early medieval England and a new hierarchical model is proposed.

Keywords: Early medieval England; Rural settlement; Settlement hierarchy; Material culture; Anglo-Saxon.

1 I would like to thank Andrew Reynolds for his advice and support in the production of this paper, as well as the assistance provided by him and Stuart Brookes throughout the completion of my $\mathrm{PhD}$ thesis, in which the dataset and many of the findings analysed in this piece were initially complied and researched. Also thank you to Juan Antonio Quirós for his assistance throughout the process. 
RESUMEN: La identificación y comprensión de la jerarquía de asentamientos en la Inglaterra medieval temprana (c siglos V-XI) son elementos complejos que han sido el foco de muchos debates. Dentro de este campo de investigación, la organización de los asentamientos, la arquitectura, los patrones de tenencia de la tierra y la cultura material se utilizan frecuentemente a la hora de identificar una tipología de asentamientos. Estos incluyen complejos regios, instituciones monásticas, ciudades y sitios relacionados con el comercio y la producción, conocidos como emporia. Esta misma evidencia también se utiliza para interpretar los estatus, rango y rol de estos sitios en la Inglaterra altomedieval. Este artículo pretende una comprensión actualizada de la jerarquía de asentamientos a través de una evaluación de los asentamientos rurales y de su cultura material. Estos sitios han recibido comparativamente menos atención académica que otros coetáneos, pero de mayor perfil social, reconocidos como centros de élite, eclesiásticos y urbanos; sin embargo, representan una rica fuente de información. A través del análisis de la cultura material como evidencia de las funciones de consumo, económicas y sociales que caracterizaron a los asentamientos rurales, se presenta un cuadro general de unas comunidades intrínsecamente complejas. Los hallazgos apoyan aún más la necesidad de reevaluar la jerarquía de asentamientos en la Inglaterra altomedieval y se propone un nuevo modelo jerárquico.

Palabras clave: Inglaterra altomedieval; Asentamientos rurales; Jerarquía de asentamientos; Cultura material; Anglosajón.

SUMMARY: 0 Introduction. 1 Studying settlement hierarchy and status in early medieval England. 2 Rural settlements of study. 3 Rural settlements: range and character of material culture. 4 Rural settlements: consumption activities. 5 Rural settlements: networks and reach. 6 Settlement hierarchy. 7 Discussion. 8 Appendix. 9 References.

\section{INTRODUCTION}

The study of settlement archaeology in early medieval England has progressed significantly in recent decades. This is primarily due to a marked rise in excavations and subsequent publications, progressing in tandem with advancing archaeological meth$\mathrm{ods}^{2}$. The increasing built environment and material culture data available for research has spurred fresh interpretations of the variety, forms and diverse characteristics of settlement types in early medieval England. This, in turn, has impelled a re-examination of the complexities of defining settlement hierarchy in the period.

This study adds to current scholarship through a focus on the material culture of early medieval rural settlements of a predominantly non-elite character (based on archaeological interpretation and academic inference), which is a largely overlooked area within the discipline ${ }^{3}$. A cross-comparative analysis of material culture from 45 excavated rural settlements is presented. Assessment of the range and character of artefacts recovered,

2 GerRard, Christopher. Medieval archaeology: Understanding traditions and contemporary approaches. London; New York: Routledge, 2003, p. 70.

3 Lewis, Hana. Pattern and process in the material culture of Anglo-Saxon non-elite rural settlements. UCL Institute of Archaeology PhD Series 1. Oxford: BAR Publishing, 2019. 
consumption patterns and the economic/production activities carried out at the rural sites reveals the social and economic complexities present within such communities, as well as strong evidence for the existence of hierarchical frameworks within, and also amongst, rural settlements. It is argued that rural settlements are not an hierarchically homogeneous group. Overall, this paper demonstrates the need for a broader reassessment of settlement hierarchy in early medieval England and a new hierarchical model is proposed.

\section{StUdying SETTLEMENT HIERARCHY AND STATUS IN EARLY MEDIEVAL ENGLAND}

Scholarship concerning settlement hierarchy is commonly reviewed through the traditional chronological divisions of early medieval England, namely the «Early Anglo-Saxon» period (c. AD410-AD650), «Middle Anglo-Saxon» period (c. AD650AD850) and "Late Anglo-Saxon» period (c. AD850-1100). These periods are referred to in the paper given the conventional ease of historical reference.

The challenges of assessing settlement hierarchy are an important element of early medieval settlement studies in England. The identification of settlement status is infrequently clear-cut, as this study demonstrates. The non-elite character of many settlements in this paper has been interpreted based on the analyses and discussions of the archaeological evidence and material culture presented in the publications consulted (Appendix). As such, alternative arguments for status are also acknowledged. One of the main challenges is that settlements can produce diverse evidence, such as building and artefact types, which may be considered indicative of the presence of both lower and higher status individuals or activities. Such complexities are discussed below.

Settlements of Early Anglo-Saxon date identified in the archaeological record are commonly interpreted as predominantly egalitarian in character, exhibiting general uniformity in arrangements 4 . Such settlements are frequently unenclosed and dispersed in terms of layout. Functional zoning, enclosures and building or property boundaries are uncommon before $c$. AD 6005. Building types in the Early Anglo-Saxon period - Grubenhäuser or sunken-featured buildings and timber post-built structures - also appear remarkably uniform across England in terms of sizes/dimensions and layout, with few constructed or surviving internal features, such as partitions or annexes ${ }^{6}$. The typically

4 i.e. Hinton, David A. "The fifth and sixth centuries: Reorganisation among the ruins». In: Karkov, Catherine E. (ed.). The archaeology of Anglo-Saxon England: Basic readings. New York: Garland Publishing Inc., 1999, p. 53-78; REYNOLDS, Andrew. "Boundaries and settlements in later $6^{\text {th }}$ to $11^{\text {th }}$ century England». In: Griffiths, David W.; Reynolds, Andrew \& Semple, Sarah (eds.). Boundaries in early medieval Britain. Anglo-Saxon Studies in Archaeology and History 12. Oxford: Oxford University School of Archaeology, 2003, p. 97-139. 130-131.

Hinton, «The fifth and sixth centuries», p. 54-55; Reynolds, «Boundaries and settlements», p.

6 i.e. Addyman, Peter V. «The Anglo-Saxon house: A new review». Anglo-Saxon England, 1972, 1, p. 273-307; Rahtz, Philip A. «Buildings and rural settlements». In: Wilson, David Mackenzie (ed.). The archaeology of Anglo-Saxon England. Cambridge: Cambridge University Press, 1976, p. 49-98; Marshall, Anne 
diffuse arrangements, limited architectural variations and lack of demarcations denoting ownership and possession could indicate that hierarchy and status were not (commonly) manifested through settlement planning or architecture. This may emphasise the tribal and kin-orientated structure of society in the Early Anglo-Saxon period, in which social bonds, status and wealth centred on exchange systems such as tribute and gift-giving?.

Within the Middle Anglo-Saxon period, progressive diversification and transformations in settlement morphology and architecture from the $c$. early $7^{\text {th }}$ century add complexities to the study of settlement hierarchy. Building and property demarcations, zoning and the enclosure of areas, such as fields with ditches or fences, become increasingly common physical examples of crop, livestock and property ownership - and therefore potential displays of wealth or status ${ }^{8}$. Building forms and construction methods also begin to vary considerably from this time, with the presence of rooms, compartments, annexes and partitions more widespread and building dimensions frequently increasing in size? .

New settlement types are distinguishable from the Middle Anglo-Saxon period, ranging from royal centres, such as palaces, and ecclesiastical institutions, including monasteries and minster (church) settlements, to trading and production settlements, known as emporia or wics, and "productive» sites which likely commonly functioned as (semi-) transient market/trading places ${ }^{10}$. The development of new settlements coincides with the consolidating power of the Anglo-Saxon kingdoms and an increasingly ranked society, reflected by the hierarchical organisation of the economy and society. The foundation of royal, elite and ecclesiastical centres supported the recognition of hierarchical

\& Marshall, Garry. "A survey and analysis of the buildings of Early and Middle Anglo-Saxon England». Medieval Archaeology, 1991, 35, p. 29-43.

Rowland, Jenny. "OE Ealuscerwen/Meoduscerwen and the concept of 'paying for mead'». Leeds Studies in English, 1990, 21, p. 1-12, p. 3-8; Hill, John M. The cultural world in Beowulf. Toronto: University of Toronto Press, 1995, p. 11; Lowry, Scott. Ritual and politics: Power negotiations at Anglo-Saxon feasts. Unpublished PhD thesis, University of North Carolina, 2003, p. 41-49, 101-104; Scull, Christopher. "Social transactions, gift exchange, and power in the archaeology of the fifth to seventh centuries». In: HAMErow, Helena; Hinton, David A. \& Crawford, Sally (eds.). The Oxford handbook of Anglo-Saxon archaeology. Oxford: Oxford University Press, 2011, p. 848-864, p. 850-851.

8 Marshall, Anne \& Marshall, Garry. "Differentiation, change and continuity in Anglo-Saxon buildings». Archaeological Journal, 1993, 150, p. 366-402; Powlesland, Dominic. "Early Anglo-Saxon settlements, structures, form and layout». In: Hines, John (ed.). The Anglo-Saxons from the migration period to the eighth century: An ethnographic perspective. Woodbridge: Boydell Press, 1997, p. 101-124, p. 106, 111-113; Hamerow, Helena. Early medieval settlements: The archaeology of rural communities in North-West Europe 400-900. Oxford: Oxford University Press, 2002, p. 97; ReYNOLds, «Boundaries and settlements», p. 104125 .

9 i.e. Marshall \& Marshall, "Differentiation, change and continuity»; Hamerow, Helena. Rural settlements and society in Anglo-Saxon England. Oxford: Oxford University Press, 2012, p. 38-40.

10 i.e. Hope-Taylor, Brian. Yeavering: An Anglo-British centre of early Northumbria. Swindon: H. M. Stationery Office, 1977; Ulmschneider, Katharina. "Central places and metal-detector finds: What are the English 'productive sites’?» In: HÅRDT, Birgitta \& Larsson, Lars (eds.). Central places in the Migration and Merovingian periods: Papers from the $52^{\text {nd }}$ Sachsensymposium, Lund. Stockholm: Almqvist \& Wiksell International, 2002, p. 333-339; BlaIr, John. The church in Anglo-Saxon society. Oxford: Oxford University Press, 2005, p. 256-261; Hodges, Richard. Dark Age economics: A new audit. London: Bloomsbury Academic, an imprint of Bloomsbury Publishing Plc., 2013. 
structures through the bestowal of property and honours, while estates and settlements, such as emporia, facilitated and participated in agricultural and production output ${ }^{11}$.

By the Late Anglo-Saxon period, hierarchy and indicators of social status are more discernible within settlement arrangements, buildings and structures, with the archaeological evidence accompanied by an increasing number of surviving written sources. For example, elite settlements like manorial complexes are often identified by distinctive features such as defensive enclosures and recognisable purpose-built structures including long ranges, kitchens and latrines ${ }^{12}$. This evidence supports the argument that, particularly by the $10^{\text {th }}$ and $11^{\text {th }}$ centuries, status and wealth were commonly manifested in landownership, for instance through estate systems including manors or the organisation of common fields (i.e. arable land) ${ }^{13}$. Such developments heralded the shift towards a more stratified society, which fostered the emergence of feudalism in England. Essentially, the holding or rent of land was exchanged for labour and services, with peasants effectively tied to the land by the landowning (gentry) classes ${ }^{14}$. Many other settlement types operating in the Late Anglo-Saxon period are also distinguishable in the archaeological record, from growing numbers of nucleated villages to fortified burghal settlements and urban centres. However, determining hierarchy amongst the diversity of settlements remains open to debate.

Any research using archaeological evidence will encounter limitations and complications with the data. Common issues include the degree of archaeological survival on a site, influenced by factors such as (un-)favourable environmental conditions; the size, scope and meticulousness of the archaeological investigations and assessments undertaken; and the scale of artefactual, flora and/or faunal assemblages collected for analysis ${ }^{15}$.

11 Hooke, Della. The landscape of Anglo-Saxon England. London; Washington: Leicester University Press, 1998, p. 39-61; Blair, The church, p. 251-253; Rippon, Stephen. Making sense of an historic landscape. Oxford: Oxford University Press, 2012, p. 150-153; Wright, Duncan W. 'Middle Saxon' settlement and society. Oxford: Archaeopress, 2015, p. 18-9.

12 Reynolds, Andrew. Later Anglo-Saxon England: Life and landscape. Stroud: Tempus, 1999, p. 60, 112-134, 149-154; Gardiner, Mark. «Late Saxon settlements». In: Hamerow, Hinton \& Crawford (eds.), The Oxford handbook of Anglo-Saxon archaeology, p. 198-217, p. 199-211; HAmerow, Helena. "AngloSaxon timber buildings and their social context». In: Hamerow, Hinton \& Crawford (eds.), The Oxford handbook of Anglo-Saxon archaeology, p. 128-155; UlmSCHneIder, Katharina. "Settlement hierarchy». In: Hamerow, Hinton \& Crawford (eds.), The Oxford handbook of Anglo-Saxon archaeology, p. 156-171, p. 165 .

13 Reynolds, Later Anglo-Saxon England, p. 123-124; Jones, Richard \& PAGE, Mark. Medieval villages in an English landscape: Beginnings and ends. Cheshire: Windgather Press, 2006, p. 6-7, 79, 82, 236; GARDINER, Mark. "Manorial farmsteads and the expression of lordship before and after the Norman Conquest». In: Hadley, Dawn M. \& Dyer, Christopher (eds.). The archaeology of the $11^{\text {th }}$ century: Continuities and transformations. Society for Medieval Archaeology monograph 38. London: Routledge, 2017, p. 88-103, p. 88-90.

14 Molyneaux, George. The formation of the English kingdom in the tenth century. Oxford: Oxford University Press, 2015, p. 41; BLAIR, John. Building Anglo-Saxon England. Princeton: Princeton University Press, 2018, p. 311-312.

15 i.e. Schiffer, Michael B. «Toward the identification of formation processes». American Antiquity, 1983, 48, p. 675-706; Schiffer, Michael B. Formation processes of the archaeological record. Albuquerque: University of New Mexico Press, 1987; Orton, Clive. Sampling in archaeology. Cambridge: Cambridge University Press, 2000, p. 6-7, 47-48, 50-51, 149, 165-166. 
An archetypal settlement case study highlighting such complexities in the interpretation of archaeological evidence is Flixborough, Lincolnshire, occupied from the $7^{\text {th }}-11^{\text {th }}$ centuries ${ }^{16}$. The remarkable preservation conditions of Flixborough, including more than 40 buildings and over 10,000 artefacts, has contributed much to discussions regarding the identification and definition of aspects of settlement status. In particular, the quantity and diversity of buildings and material culture has led to various interpretations of the status, character and functions of Flixborough, which may have changed over the occupation of the settlement. Evidence such as the presence or absence in occupation phases of material culture including coins, styli, jewellery, imported goods and utilitarian items has led to suggestions that Flixborough may have variously served as a non-elite settlement, a monastic site and/or an aristocratic centre ${ }^{17}$. However, reaching such conclusions from archaeological evidence can be impacted by a range of variables. For example, the opportune survival conditions of a site may inadvertently reflect the profile of an exceptionally prosperous or prolific settlement within the archaeological record. Also, material culture evidence may in some cases be broadly unrepresentative of actual settlement consumption patterns. For instance, objects of sentimental value or those considered luxurious, including heirlooms and items made of costly or exotic materials, can benefit from greater (relative) survival rates in the archaeological record. This is because such items have a higher likelihood of being cared for than commonplace or more easily replaceable goods such as basic cookware or tools ${ }^{18}$.

The classification of forms and functions of material culture is also subjective and has an impact on interpretation. For example, the presence of objects suggestive of literacy commonly associated with ecclesiastical activities, such as styli and inkwells, may be used as contributory evidence concerning the religious character of a settlement. However, it can be argued that literacy was just as integral for administrative purposes, such as estate management or royal business, emphasising the importance of considering potential myriad uses of material culture. The identification of prestigious and opulent items is also not a straightforward process. Artefacts may be considered prestige, regarding tangible or perceived worth, by various characteristics including: superior workmanship; desirable materials such as gold or silver; use; circulation; comparative rarity or limitations in terms of item accessibility; expense; and provenance ${ }^{19}$. Adding to the complexity, such values attached to the significance of an item may vary or fluctuate over time and within

16 i.e. Loveluck, Christopher. «Wealth, waste and conspicuous consumption: Flixborough and its importance for Middle and Late Saxon rural settlement studies». In: Hamerow, Helena \& MacGregor, Arthur (eds.). Image and power in the archaeology of early medieval Britain: Essays in honour of Rosemary Cramp. Oxford: Oxbow Books, 2001, p. 78-130; Evans, D. H. \& Loveluck, Christopher (eds.). Life and economy at early medieval Flixborough c. AD600-1000. Excavations at Flixborough Volume 2. Oxford: Oxbow Books, 2009.

17 i.e. LovelucK, Christopher. Rural settlement, lifestyles and social change in the later first millennium AD: Anglo-Saxon Flixborough in its wider context. Excavations at Flixborough Volume 4. Oxford: Oxbow Books, 2007.

18 Clegg Hyer, Maren \& Owen-Crocker, Gale R. (eds.). The material culture of daily living in the Anglo-Saxon world. Exeter: University of Exeter Press, 2011, p. 2.

19 i.e. Wiскнам, Christopher. Framing the early Middle Ages: Europe and the Mediterranean, 400-800. Oxford: Oxford University Press, 2005, p. 696, 808. 
different places. This is highlighted by issues of regionality in early medieval England, as a range of settlements located in proximity to the east coast produce prolific and diverse material culture assemblages as compared to many sites in other regions. In some cases, this does not necessarily indicate the elite status of settlements with abundant material culture; rather, it reflects the advantageous maritime and land trade, communication and travel networks that radiated from the eastern seaboard, facilitating the supply and demand of various goods ${ }^{20}$.

Given such matters, the presence/absence, types and quantities of artefacts - notably "prestige» or rare items - can only be interpreted as indicators of settlement and social rank with some reservations, as sites like Flixborough highlight ${ }^{21}$. Functions undertaken at settlements, as commonly evidenced by material culture, also stress the difficulties in assessing hierarchy. For instance, not all elite secular or ecclesiastical centres engaged in conspicuous consumption - the acquisition of goods or services for the purpose of expressing wealth - which is a strong indicator of status. Further, many activities such as craft working, trade and agricultural or commodity production were commonly undertaken at low and high status settlements ${ }^{22}$. These conditions have contributed to Loveluck's proposal of a «dynamic change» model in place of a conventional «high status» classification, which he argues does not accurately reflect the complexities of settlement character ${ }^{23}$. Katharina Ulmschneider also advocates the reconsideration of traditional settlement categorisations and hierarchy in early medieval England, notably the "monarcho-centric» view in which recognition of the versatility of settlements is limited, with royal, aristocratic and ecclesiastical centres ranking above all other sites ${ }^{24}$.

Some hierarchical models for early medieval settlements have been offered beyond the «monarcho-centric» structure, notably based on economic factors and other settlement roles and functions. For instance, Christopher Dyer and Keith Lilley have presented a model which considers settlements by broad urban and rural classification, with the highest status sites - all of urban character - including (regional) capitals below which are types of towns (i.e. provincial, regional), followed by rural communities that are represented by villages, which rank above both hamlets and, then, farmsteads as the lowest hierarchical tier. The model encompasses the complexities of settlement character, acknowledging that the individual status of urban and rural settlements within the categories would reflect factors such as the activities, occupations and roles supported by

20 Loveluck, Christopher. Northwest Europe in the early Middle Ages, c. AD600-1150: A comparative archaeology. Cambridge: Cambridge University Press, 2013, p. 98-99.

21 Hamerow, Rural settlements and society, p. 101; Loveluck, Christopher. «Central-places, exchange and maritime-oriented identity around the North Sea and western Baltic, AD600-1100». In: GeLICHI, Sauro \& Hodges, Richard (eds.). From one sea to another: Trading places in the European and Mediterranean early Middle Ages. Proceedings of the International Conference Comacchio, 27 th $-29^{\text {th }}$ March 2009. Turnhout: Brepols, 2012, p. 123-165, p. 139.

22 Loveluck, Rural settlement, lifestyles and social change, p. 99-100.

23 Loveluck, Rural settlement, lifestyles and social change, p. 147.

24 Ulmschneider, Settlement hierarchy, p. 156-157, 162-163. 
the communities as well as settlement size ${ }^{25}$. Ben Palmer has suggested an hierarchical model comprising: the emporia production and trading specialised sites as the highest ranking; below which are settlements that served as central foci and possessed markets; followed by rural settlements that supported specialised production, and in some cases incorporated ecclesiastical functions; and at the lowest rank, rural settlements producing (only) occasional surpluses ${ }^{26}$. Palmer's model is pertinent to the Middle Anglo-Saxon period, when the emporia were operational. John Moreland has put forward an hierarchical framework constituting: major successful ecclesiastical centres as highest ranking; below which are thriving but comparatively less well-resourced and/or economically successful settlements; followed by settlements predominantly involved in rural production; and, as the lowest rank, various sites commonly somewhat elusive in the archaeological record which provided services to a range of other settlements ${ }^{27}$.

Building types and functions may also evidence elements of settlement hierarchy and social distinctions within communities, however not without complications in interpretation. Particularly in settlements of Early and Middle Anglo-Saxon date, common challenges faced in identifying the use(s) and potential status of settlement buildings include either the lack of surviving evidence for construction techniques/styles or internal features, such as floors and partitions, and a dearth of material culture associated with the contemporary functions of buildings ${ }^{28}$. A paucity of artefactual evidence could indicate that some halls and residences, often post-built structures, were regularly maintained and cleaned which possibly reflects the higher status of such buildings ${ }^{29}$. Also, ephemeral settlements may leave little evidence in the archaeological record due to their temporary structural nature, such as transient marketplaces and trade/exchange sites or temporary bases for travelling royal retinues.

Studies of hierarchical status as inferred from building forms, designs and sizes have often focused on the uses of post-built structures in the pursuit of identifying "great» or «royal» halls referred to in written sources, including famously the Old English epic poem Beowulf ${ }^{0}$. In contrast, initial studies of Grubenhäuser considered these structures - comprising a shallow pit covered by a floor beneath the roofed building area - as

25 Dyer, Christopher \& Lilley, Keith. "Town and countryside: Relationships and resemblances». In: Christie, Neil \& Stamper, Paul (eds.). Medieval rural settlement: Britain and Ireland, AD800-1600. Bollington: Windgather, 2011, p. 81-98, p. 83.

26 Palmer, Ben. "The hinterlands of three southern English emporia: Some common themes». In: Pestell, Tim \& Ulmschneider, Katharina (eds.). Markets in early medieval Europe: Trading and "productive» sites, 650-850. Macclesfield: Windgather Press, 2003, p. 48-60, p. 53-55.

27 Moreland, John F. «The significance of production in eighth century England». In: Hansen, Inge Lise \& Wicкнам, Christopher (eds.). The long eighth century: Production, distribution and demand. Leiden: Brill, 2000, p. 69-104, p. 96-97.

28 Hamerow, «Anglo-Saxon timber buildings», p. 136-141.

29 Hinton, David A. Gold and gilt, pots and pins: Possessions and people in medieval Britain. Oxford: Oxford University Press, 2005, p. 72.

30 i.e. Cramp, Rosemary J. "Beowulf and Archaeology». Medieval Archaeology, 1957, 1, p. 57-77; UlMSCHNEIDER, «Settlement hierarchy», p. 156, 162-163. 
uniformly low status. ${ }^{31}$ Subsequent research has led to suggestions of a range of functions for these buildings, from domestic to ancillary and workshop (notably textile) purposes. Grubenhäuser are more common within settlements of Early Anglo-Saxon date, often as the ubiquitous building type, and this has contributed to the prevailing view of rural settlements at this time as apparently egalitarian in character ${ }^{32}$. However, the reassessment of the potential status attributable to Grubenhäuser has merit. There is debate surrounding the possible construction of some Grubenhäuser with suspended planked floors, a design which could have formed a two-storeyed building with a considerable floor area and greater air circulation on par with many post-built structures ${ }^{33}$. The constructional skill and levels of costs, resources and labour likely needed to build such Grubenhäuser has been noted by Helena Hamerow as comparable with post-built structures and, as such, is plausibly indicative of hierarchy and status ${ }^{34}$.

Archaeological excavations have revealed that post-built structures generally increase in size as well as design variations and sophistication from the $c$. $7^{\text {th }}$ century on. However, arguably few buildings currently known, dating prior to the Late Anglo-Saxon period, are of a size or the apparent grandeur comparable to written descriptions of great halls ${ }^{35}$. Moreover, larger sized buildings could have served a range of functions beyond the royal or grand, for example as storage facilities for commodities, barns for livestock or perhaps as communal halls to meet various settlement needs. Again, with a lack of definitive supporting evidence such as material culture, this is an area of settlement studies which is subject to debate and requires further investigation. Transformations witnessed, particularly in the Middle Anglo-Saxon period, with the increasing size and diversity of buildings, as well as new types of settlements exhibiting variations in layout and character, highlight complexities in defining hierarchy as both low and high status settlements could share structural, organisational as well as consumption characteristics ${ }^{36}$.

Overall, particularly given the challenges, there is wide scope for further research within all approaches to the study of settlement hierarchy in early medieval England. The aim of this paper is to contribute to settlement hierarchy studies by assessing rural settlements and their material culture, which have received less academic focus than other settlement types in early medieval England.

31 i.e. Radford, C. A. Ralegh. "The Saxon house: A review and some parallels». Medieval Archaeology, 1957,1 , p. 27-38, p. 29; Addyman, «The Anglo-Saxon house», p. 274-276.

32 i.e. Hinton, «The fifth and sixth centuries», p. 54-55; Reynolds, "Boundaries and settlements», p. 130-131.

33 Powlesland, Early Anglo-Saxon settlements, p. 110-113; Tipper, Jess. The grubenhaus in AngloSaxon England: An analysis and interpretation of the evidence from a most distinctive building type. Yedingham, North Yorkshire: Landscape Research Centre, 2004, p. 184; Hamerow, Rural settlements and society, p. 64.

34 HaMEROW, Rural settlements and society, p. 59-65.

35 i.e. Marshall \& Marshall, "Differentiation, change and continuity in Anglo-Saxon buildings»; ULMSCHNEIDER, "Settlement hierarchy», p. 159-162.

36 UlmsChNEIDER, "Settlement hierarchy», p. 161-162. 


\section{RURAL SETTLEMENTS OF STUDY}

Settlement morphology and material culture evidence was compiled from 45 sites in order to undertake a comparative study of the profiles and character of early medieval rural settlements. The dataset was originally compiled for the author's doctoral thesis ${ }^{37}$.

All the sites are in England and have been subject to excavation and publication of the results (Figure 1; Appendix). Unpublished sites were deliberately excluded, largely due to the time limitations of the project and the potential impracticalities of locating and accessing unpublished materials. Completed works also had the common advantage of facilitating greater analysis and interpretation of excavated settlement sites and material culture assemblages.

The aim was to produce a varied dataset, with 45 sites that were diverse in terms of settlement arrangements, sizes and architecture ${ }^{38}$. Further, the settlement occupation dates span the early medieval period $\left(c .5^{\text {th }}-11^{\text {th }}\right.$ centuries) and the sites are located across England. However, it is acknowledged that some areas of the country have little or no representation in the dataset. This will ideally be addressed by future research, for example through comparison and expansion of the dataset with settlements in Kent, a region politically, socially and economically distinct from the rest of England at the beginning of the early medieval period ${ }^{39}$. There is an apparent dataset bias in favour of the east and parts of south England, primarily as a result of the greater number of excavations undertaken and subsequently published in these regions (Figure 1). However, there is also a feasible argument to be made for a likely "Anglo-Saxon cultural zone», as discussed by John Blair, which could partially account for the high archaeological visibility in these areas ${ }^{40}$.

The settlements also exhibit differences in character and development. For instance, Staunch Meadow (Brandon), Suffolk is considered an elite settlement and due to this it has been included as a particular contrast to the other sites ${ }^{41}$. It has been suggested, primarily owing to architectural evidence, that Cowdery's Down, Hampshire may have also been a settlement of significant status ${ }^{42}$. The greater area of Sutton Courtenay/Drayton, Oxfordshire is considered to comprise low and high status settlements in proximity to one another ${ }^{43}$. As further examples, the three settlements of Goltho, Lincolnshire and

37 Lewis, Pattern and process, p. 17-18. html

38 Lewis, Pattern and process, Appendix 1, https://www.barpublishing.com/additional-downloads.

39 i.e. Brookes, Stuart. Economics and social change in Anglo-Saxon Kent AD400-900: Landscapes, communities and exchange. BAR British Series 431. Oxford: BAR Publishing, 2007, p. 18-21.

40 Blair, Building Anglo-Saxon England, p. 25-35.

41 Tester, Andrew; Anderson, Sue; Riddler, Ian \& Carr, Robert. Staunch Meadow, Brandon, Suffolk: A high status Middle Saxon settlement on the fen edge. East Anglian Archaeology 151. Bury St Edmonds: Suffolk County Council Archaeological Service, 2014.

42 Millett, Martin \& James, Simon. «Excavations at Cowdery’s Down, Basingstoke, Hampshire, 1978-81». Archaeological Journal, 1983, 140, p. 151-279.

43 i.e. Hamerow, Helena; Hayden, Chris \& Hey, Gill. «Anglo-Saxon and earlier settlement near Drayton Road, Sutton Courtenay, Berkshire». Archaeological Journal, 2007, 164, p. 109-196; BrennAN, Naomi \& Hamerow, Helena. "An Anglo-Saxon great hall complex at Sutton Courtenay/Drayton, Oxfordshire: A royal centre of early Wessex?». Archaeological Journal, 2015, 172, p. 325-350. 
Raunds Furnells and West Cotton in Northamptonshire developed into manorial centres $^{44}$. Also, it has been argued that Cottam, East Yorkshire may have been a "productive» site or similar ${ }^{45}$. Overall, the study produces new evidence focused on rural settlements that can contribute to the assessment of settlement hierarchy in early medieval England.

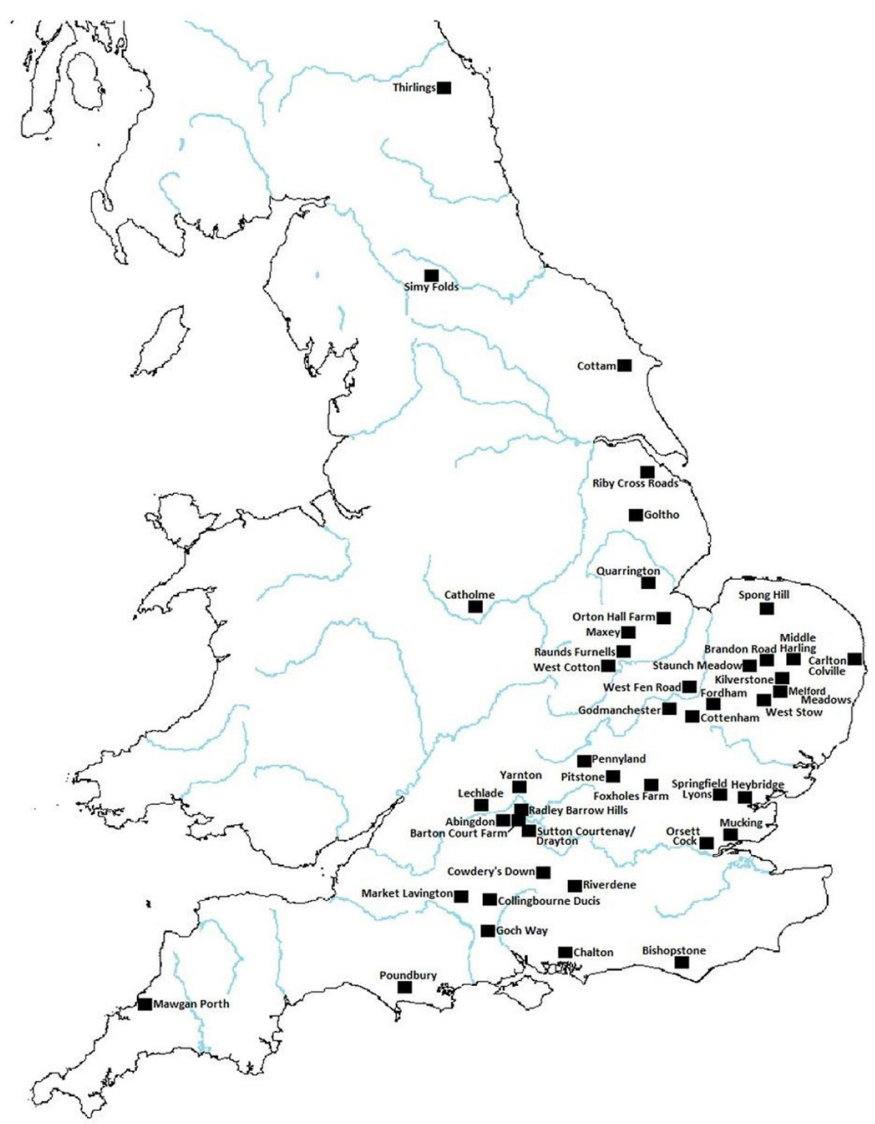

FIGURE 1. Distribution map of the settlements. Lewis 2019, Fig 1.1, page 2. Reproduced with the permission of BAR Publishing.

44 Beresford, Guy. Goltho: The development of an early medieval manor c. 850-1150. London: Historic Buildings and Monuments Commission for England, 1987; Audouy, Michel \& Chapman, Andy (eds.). Raunds: The origin and growth of a midland village AD450-1500. Excavations in north Raunds, Northamptonshire 1977-87. Oxford: Oxbow Books, 2009; Chapman, Andy. West Cotton, Raunds. A study of medieval settlement dynamics AD450-1450: Excavation of a deserted medieval hamlet in Northamptonshire, 1985-89. Oxford: Oxbow Books, 2010.

45 i.e. Richards, Julian D. "What's so special about 'productive sites'? Middle Saxon settlements in Northumbria». In: Dickinson, Tania M. \& Griffiths, David W. (eds.). The making of kingdoms: Papers from the $47^{\text {th }}$ Sachsen symposium, York, September 1996. Anglo-Saxon studies in archaeology and history 10. Oxford: Oxford University Committee for Archaeology, 1999, p. 71-80. 


\section{RuRAL SETTLEMENTS: RANGE AND CHARACTER OF MATERIAL CULTURE}

The assessment of the types and character of material culture found at the settlements reveals the social and economic sophistication of many of these rural communities, notwithstanding the challenges of interpreting the archaeological record as discussed above. Material culture evidence also points towards hierarchical structures within, and amongst, rural settlements ${ }^{46}$.

All recorded material culture from the sites was collated to maximise the data available for analysis ${ }^{47}$. This comprised objects deriving from stratified (archaeological contexts constituting a site) as well as unstratified and metal detected settings (both non-archaeological contexts associated with a site). The artefacts were then classified by type and form (Table 1). These categories are based on the excavators' and specialists' interpretations as recorded in the published materials consulted and conventional interpretations where information was lacking. It is recognised that such interpretations of material culture evidence - especially forms and functions - can be subjective. For example, multi-purpose tools such as shears, awls or chisels could have been used for a range of utilitarian, manufacturing and/or agricultural purposes.

\begin{tabular}{|l|l|}
\hline Category & Material culture \\
\hline $\begin{array}{l}\text { Receptacles, containers, } \\
\text { plates \& vessel fittings }\end{array}$ & $\begin{array}{l}\text { Cooking, eating \& serving items (i.e. bowls, cooking pots, briquetagé, } \\
\text { dishes, plates, platters, skillets); Drinking, holding liquids \& storage items } \\
\text { (i.e. jars, cups, beakers, vessels, pitchers, pots/storage pots, flagon); Buckets; } \\
\text { Funerary vessels; Escutcheons; Miscellaneous vessels; Vessel fittings \& repairs }\end{array}$ \\
\hline Utensils & $\begin{array}{l}\text { Knives; Hooks; Spoons/spatulas; Strike-a-lights; Laundering items; } \\
\text { Miscellaneous utensils }\end{array}$ \\
\hline Domestic items & Mounts; Plaques; Lamps; Basins \\
\hline Security \& privacy & Locks; Padlocks; Keys; Latch lifters; Caskets; Boxes; Chests \\
\hline $\begin{array}{l}\text { Ornamentation \& } \\
\text { jewellery }\end{array}$ & $\begin{array}{l}\text { Pins; Beads; Brooches; Finger rings; Pendants; Bracelets/armlets/bands; } \\
\text { Miscellaneous adornment }\end{array}$ \\
\hline Dress & $\begin{array}{l}\text { Strap ends; Hair/dress pins; Buckles; Hooked tags; Belt \& leather fittings; } \\
\text { Wrist clasps; Studs; Discs; Girdle hangers; Miscellaneous dress }\end{array}$ \\
\hline Charms & Amulets; Norse bells \\
\hline Cosmetic & Tweezers; Cosmetic spoons; Cosmetic pins/prickers; Cosmetic fittings \\
\hline Grooming \& hygiene & Combs; Ear scoops; Nail cleaners; Razors \\
\hline Utilitarian equipment & $\begin{array}{l}\text { Agricultural tools; Processing tools; Manufacturing tools; Multi-purpose } \\
\text { tools; Sharpening tools; Weights; Rubbers/pounders; Measuring tools; } \\
\text { Miscellaneous tools; Fixtures; Fittings }\end{array}$ \\
\hline Manufacturing & $\begin{array}{l}\text { Textile working; Metal working; Other manufacturing evidence (i.e. bone, } \\
\text { leather, wood, pottery \& ?glass working) }\end{array}$ \\
\hline Weaponry & $\begin{array}{l}\text { Spearheads; Spear accessories; Arrowheads; Seaxes; Sword parts \& } \\
\text { accessories; Shield accessories; Missile weapons \& missiles }\end{array}$ \\
\hline
\end{tabular}

46 Lewis, Pattern and process, esp. p. 219-28, 235-49.

47 Lewis, Pattern and process, i.e. Appendices 3-4, https://www.barpublishing.com/additional-downloads.html. 


\begin{tabular}{|l|l|}
\hline Category & Material culture \\
\hline Animal equipment & $\begin{array}{l}\text { Horseshoes \& horseshoe nails; Bridle equipment; Harness, belt \& spur } \\
\text { fittings; Spurs; Bells \& bell-clappers; Stirrup \& strap mounts }\end{array}$ \\
\hline Trade \& exchange & Coins; Coin equipment; Measuring weights \& vessel \\
\hline Literacy & $\begin{array}{l}\text { Styli; Inkwells; «Slate» pencils; ?Book page clip; ?Parchment pricker; ?Book } \\
\text { mounts; Inscribed artefacts (Latin, Anglo-Saxon runes, Lombardic) }\end{array}$ \\
\hline Amusement & Counters \& gaming pieces; Other amusement items \\
\hline Building material & $\begin{array}{l}\text { Stone building/structural material; Bricks/tiles; Un/fired clay \& daub; } \\
\text { Window glass; Ladder-like object }\end{array}$ \\
\hline Prehistoric artefacts & Flint; Pottery; Brooches; Beads; Awl; Arrow-/spearhead; Pin; Coin \\
\hline Roman artefacts & $\begin{array}{l}\text { Pottery; Coins; Miscellaneous metal artefacts including knives, keys, } \\
\text { brooches, tools \& slag; Miscellaneous bone artefacts including pins; } \\
\text { Miscellaneous stone artefacts including bracelets \& Niedermendig lava } \\
\text { querns; Miscellaneous ceramic artefacts including counters; Miscellaneous } \\
\text { glass artefacts including beads \& vessels; Jet; Building material }\end{array}$ \\
\hline
\end{tabular}

TABLE 1. Material culture at the settlements.

The quantities of the catalogued material culture assemblages from the settlements range from thousands of artefacts to several hundred, down to under 100 examples and individual objects (Table 2). A strong statistical representation of minority objects across the sites is apparent. However, all the evidence adds to our understanding of rural settlements. Also, in some cases, the variations in artefact quantities will be indicative of patterns of use as well as the apparent value attached to certain objects. For example, everyday domestic and utilitarian items such as pottery vessels and tools or implements are found in larger amounts than items made of rarer or harder to obtain materials such as gold and silver.

\begin{tabular}{|l|l|}
\hline No. of artefacts & Artefact types \\
\hline $160000_{+}$ & Cooking, eating, drinking, serving \& storage items \\
\hline $4000_{+}$ & Querns \\
\hline $100+_{+}$ & Fixtures; Loomweights \\
\hline $800+$ & Metal sheets/strips \\
\hline $500+$ & Knives \\
\hline $400+$ & Fittings \\
\hline $300+$ & Pins; Spindlewhorls \\
\hline $200_{+}$ & Combs \\
\hline $100+$ & $\begin{array}{l}\text { Beads; Brooches; Coins; Hair/dress pins; Hones \& sharpeners; Pinbeaters; Strap } \\
\text { ends }\end{array}$ \\
\hline $1+$ & $\begin{array}{l}\text { Amusement; Animal equipment; Charms; Cosmetic; Domestic; Dress; Economic } \\
\text { apparatus; Funerary; Grooming; Household; Jewellery; Literacy; Manufacturing; } \\
\text { Security; Tools; Utensils; Weaponry; Miscellaneous cooking equipment, objects \& } \\
\text { vessels }\end{array}$ \\
\hline
\end{tabular}

TABLE 2. Early medieval artefact quantities (approximated) from the settlements. 
Limitations with the dataset include the varying survival rates of the archaeological record as well as the archaeological investigations undertaken, which can differ in terms of size, excavation methods employed (i.e. metal detecting etc.) and budgeting or time constraints. Further, there were instances of omissions, discrepancies and approximations regarding the artefacts and quantities recorded in the published materials consulted ${ }^{48}$. Despite such challenges, a significant quantity of diverse material culture was recovered and interpreted from the sites which illuminate many aspects of rural settlement life.

By far the largest assemblage is the cooking, eating, drinking, serving and storage collection, which produces over 160,000 artefacts as a result of the significant sizes of the pottery assemblages recovered from a number of the settlements ${ }^{49}$. Sixteen other assemblages which are varied in form and function total more than 100 artefacts. These comprise manufacturing/production-related objects (i.e. querns, loomweights, pinbeaters etc.); domestic utensils, utilitarian tools and implements (i.e. knives, fixtures, fittings etc.); personal adornment, dress and grooming items (i.e. beads, strap ends, combs etc.); and coins of early medieval date (sceattas, stycas and pennies) which indicate trade and exchange activities.

The remaining assemblages, which exhibit further diversities in type and character, comprise less than 100 artefacts each and there are also single examples. These assemblages include weapons, equestrian equipment, writing/reading implements, security items such as locks and keys, amusement objects including gaming counters, and items (potentially) associated with funerary rites such as urn sherds. It must be noted that other artefacts may have had ritual and funerary significance attributed to them which are not currently discernible in the archaeological record.

Several of the artefact collections from the rural settlements may particularly contribute to debates concerning social and settlement hierarchy. The groups considered as such are: weapons; equestrian equipment; objects interpreted as prestige; coins; glass vessels; and items associated with literacy ${ }^{50}$. As discussed above, these artefact collections are either conventional indicators of potential status and wealth or, at the very least, are representative of social and economic diversification within rural settlements. It is acknowledged that such interpretations of the evidence are subjective, serving to highlight the complexities of studying hierarchy in the archaeological record.

Weapons and equestrian equipment point towards bellicose pursuits, hunting as well as horse ownership and, as such, are conventionally associated with the elite and otherwise commanding or prosperous individuals, such as warriors, soldiers or nobles. The skill of literacy is regarded as the chief domain of ecclesiastics, members of the elite and royal or government officials. As discussed above, prestige items have been defined by characteristics including quality and workmanship which likely contribute to restrictions on the acquisition and circulation of such objects, adding to their value and signifying levels of affluence ${ }^{51}$. Coins represent portable wealth as well as a mechanism

48 Lewis, Pattern and process, p. 30-4.

49 Lewis, Pattern and process, p. 122-125.

50 Lewis, Pattern and process, p. 219-228.

51 Wiскнам, Framing the early Middle Ages, p. 696, 808. 
for transactional activities and, as such, may be indicative of degrees of prosperity and/ or status. Finally, glass vessels are relatively uncommon items within rural settlements and may therefore be indicative of affluence in some instances, with examples likely used during social interactions such as feasts ${ }^{52}$.

These assemblages were collectively recovered from 35 of the 45 settlements of study. Even allowing for the variations in the extent of excavations and rates of archaeological survival, the evidence demonstrates elements of social distinction and hierarchy within a range of rural settlements. The settlements differ in occupation dates, locations, sizes as well as layout, organisation and building types ${ }^{53}$. This highlights that an array of factors, encompassing social and economic circumstances and degrees of prosperity, must have supported and cultivated settlement and social hierarchies.

Regarding the occurrence of these assemblages across the sites, weapons and weapon accessories are most commonly represented, with established and likely examples recorded at 24 settlements - over half the sites of study (Figure 2). The assemblage includes spear- and arrowheads, spear and shield fittings as well as sword parts. Second most commonly represented at the settlements is equestrian equipment, including horseshoes, spurs, harness parts and bridle apparatus, with 20 sites producing established and likely examples. Seventeen settlements produce over 60 objects considered prestige, including jewellery, dress accessories, equestrian equipment and weapons. Most of these objects derive from Staunch Meadow (Brandon), which is considered a high-status settlement ${ }^{54}$. However, the presence of such objects at 16 other sites is significant, indicating wealth and social diversification in a range of rural communities. Thirteen of the settlements produce 161 contemporary coins, encompassing sceattas, stycas and pennies of various English and Continental provenance as well as one central Asian example. Glass vessels have been identified at 13 settlements, including sherds from beakers, cups and at least one flask, some of which were coloured or decorated. Literacy is potentially represented at nine settlements, with evidence including writing implements such as styli and a possible parchment pricker as well as a selection of objects with Latin, Anglo-Saxon runes or Lombardic inscriptions.

These assemblages highlight elements of social variation within rural settlements, beyond elite, ecclesiastical and urban sites or furnished cemeteries with which such items are more commonly associated. Weapons, equestrian equipment and evidence for literacy strongly suggest the presence and association within some rural settlements of distinguished and specialised individuals, such as warband members, administrative officials (whether secular or ecclesiastical) and elite persons. Prestige items, coins and possibly glass vessels signify portable wealth and indicate levels of prosperity and affluence.

52 i.e. Rowland, «OE Ealuscerwen/Meoduscerwen», p. 3-8; Lowry, Ritual and politics, p. 41-49, 101-104.

53 Lewis, Pattern and process, p. 219-228, Appendix 1, https:/www.barpublishing.com/additionaldownloads.html.

54 Tester et. al., Staunch Meadow, Brandon, Suffolk. 


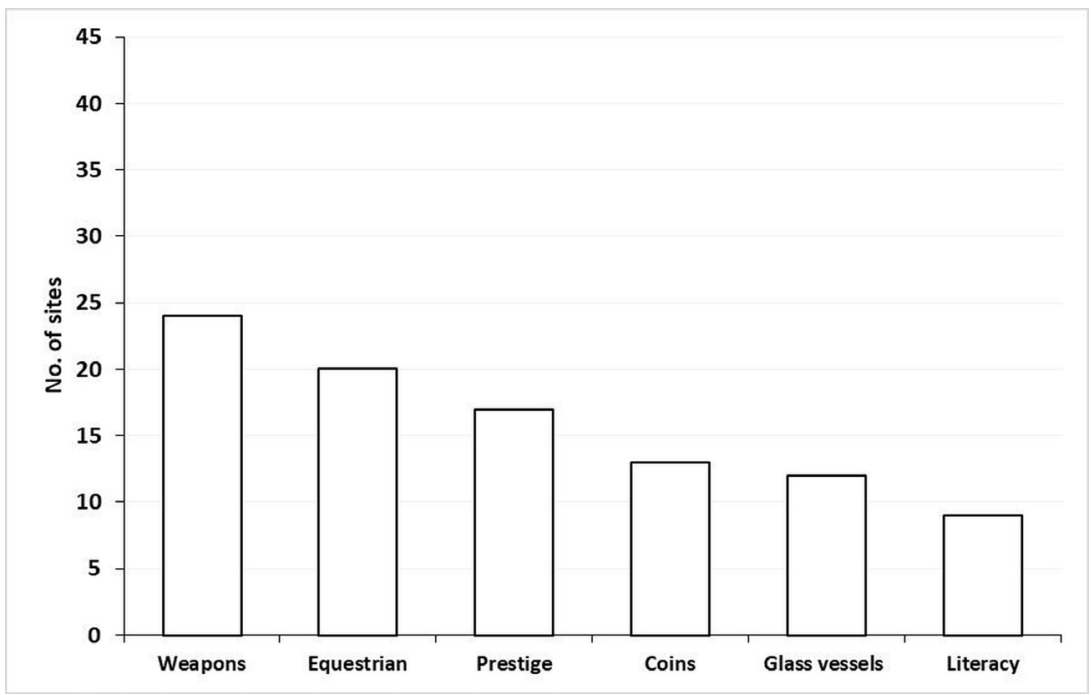

FIGURE 2. Material culture hierarchical indicator groups at the settlements.

Overall, the range and character of material culture from rural settlements is diverse and demonstrates the hierarchical, social and economic sophistications of many of these communities, including the undertaking of various activities and occupations.

\section{RURAL SETTLEMENTS: CONSUMPTION ACTIVITIES}

Patterns of consumption evidenced by material culture at the rural settlements demonstrate the multifaceted character of many of these communities. Notably, a range of livelihoods and activities beyond the typical rural sphere were undertaken and the presence of social diversities and likely hierarchical structures are apparent ${ }^{55}$.

Through interpreting the material culture as indicative of cultural and behavioural practices, 18 broad consumption activities were identified across the settlements (Table 3). It must be noted that, as with the classification of material culture from which this assessment stems, such interpretations are unavoidably subjective and alternative functions and uses may be proposed in some instances ${ }^{56}$.

55 Lewis, Pattern and process, p. 126-172, Appendix 5 https:/www.barpublishing.com/additionaldownloads.html.

56 Lewis, Pattern and process, p. 24-27. 


\begin{tabular}{|c|c|c|}
\hline $\begin{array}{l}\text { Consumption } \\
\text { activities }\end{array}$ & $\begin{array}{l}\text { Material culture } \\
\text { interpretation }\end{array}$ & Material culture examples \\
\hline $\begin{array}{l}\text { Domestic \& } \\
\text { household }\end{array}$ & $\begin{array}{l}\text { Cooking, eating/drinking } \& \\
\text { storage objects; Household } \\
\text { items; Personal possessions }\end{array}$ & $\begin{array}{l}\text { Bowls; Cooking pots; Storage containers/pots; } \\
\text { Dishes; Plates; Platters; Skillets; Briquetagé; Jars; } \\
\text { Cups; Beakers; Vessels; Pitchers; Flagon; Buckets; } \\
\text { Funerary vessels; Escutcheons; Vessel fittings \& } \\
\text { repairs; Knives; Hooks; Spoons/spatulas; Strike- } \\
\text { a-lights; Laundering items; Utensils; Mounts; } \\
\text { Plaques; Lamps; Basins; Locks; Padlocks; Keys; } \\
\text { Latch lifters; Caskets; Boxes; Chests }\end{array}$ \\
\hline $\begin{array}{l}\text { Ornamentation, } \\
\text { dress \& grooming }\end{array}$ & $\begin{array}{l}\text { Personal adornment/jewellery; } \\
\text { Dress \& clothing accessories; } \\
\text { Cosmetic objects; Hygiene } \\
\text { items }\end{array}$ & $\begin{array}{l}\text { Pins; Beads; Brooches; Finger rings; Pendants; } \\
\text { Bracelets/armlets/bands; Miscellaneous } \\
\text { adornment; Strap ends; Hair/dress pins; Buckles; } \\
\text { Hooked tags; Belt \& leather fittings; Wrist clasps; } \\
\text { Studs; Discs; Girdle hangers; Miscellaneous } \\
\text { dress; Tweezers; Cosmetic spoons; Cosmetic } \\
\text { prickers/ pins; Cosmetic fittings; Combs; Ear } \\
\text { scoops; Nail cleaners; Razors }\end{array}$ \\
\hline Utilitarian & Practical objects & Tools \& implements; Fixtures; Fittings \\
\hline $\begin{array}{l}\text { Manufacture, } \\
\text { production \& } \\
\text { craft }\end{array}$ & $\begin{array}{l}\text { Artefacts evidencing } \\
\text { production- textile, metal, } \\
\text { bone, leather, wood, pottery \& } \\
\text { ?glass working }\end{array}$ & $\begin{array}{l}\text { Manufacturing tools \& } \& \text { implements; } \\
\text { Manufacturing debris \& offcuts }\end{array}$ \\
\hline $\begin{array}{l}\text { Agriculture, } \\
\text { cultivation \& } \\
\text { horticulture }\end{array}$ & $\begin{array}{l}\text { Agrarian, gardening \& } \\
\text { cultivation related objects }\end{array}$ & $\begin{array}{l}\text { Agricultural tools; Processing tools; Livestock } \\
\text { bells }\end{array}$ \\
\hline $\begin{array}{l}\text { Warfare \& } \\
\text { defence }\end{array}$ & $\begin{array}{l}\text { Warfare/defence related } \\
\text { objects }\end{array}$ & Weapons; Weapon accessories; Missiles \\
\hline $\begin{array}{l}\text { Hunting \& } \\
\text { fishing }\end{array}$ & $\begin{array}{l}\text { Hunting \& fishing related } \\
\text { objects }\end{array}$ & $\begin{array}{l}\text { Spear- \& arrowheads; Seaxes; Slingshots; } \\
\text { ?Archer's wrist guard; Fishing weights \& hooks; } \\
\text { Netsinkers; Mussel scoop; Fishnet float or rope } \\
\text { tackle; ?Harpoon blade; ?Norse bells }\end{array}$ \\
\hline Equestrian & Animal equipment $\&$ items & $\begin{array}{l}\text { Horseshoes \& nails; Spurs; Fittings; Bridle, belt } \\
\& \text { harness apparatus; Mounts; Bells; ?Norse bells }\end{array}$ \\
\hline Leisure & $\begin{array}{l}\text { Amusement objects (potential } \\
\text { leisurely/sport pursuits such as } \\
\text { equestrian, hunting \& fishing } \\
\text { considered separately) }\end{array}$ & $\begin{array}{l}\text { Counters; Gaming pieces; Ice skates; ?Toy horse } \\
\text { figure; ?Whistle }\end{array}$ \\
\hline $\begin{array}{l}\text { Trade \& } \\
\text { exchange }\end{array}$ & $\begin{array}{l}\text { Artefacts associated with trade } \\
\& \text { exchange (monetary } \& \\
\text { barter transactions etc.) }\end{array}$ & $\begin{array}{l}\text { Coins; Coin equipment (scale pan, ?coin } \\
\text { mould); Commodity measuring apparatus } \\
\text { (equal armed/equipoise weights, balance \& scale } \\
\text { weights, ?weighing vessel); ?Trade token }\end{array}$ \\
\hline
\end{tabular}




\begin{tabular}{|c|c|c|}
\hline $\begin{array}{l}\text { Consumption } \\
\text { activities }\end{array}$ & $\begin{array}{l}\text { Material culture } \\
\text { interpretation }\end{array}$ & Material culture examples \\
\hline Prestige \& luxury & $\begin{array}{l}\text { Items likely denoting } \\
\text { privilege, wealth or rank \& } \\
\text { social distinctions, in terms } \\
\text { of materials, workmanship } \\
\text { or restrictions of acquisition/ } \\
\text { supply }\end{array}$ & $\begin{array}{l}\text { Badorf \& Tating ware; Personal adornment; } \\
\text { Dress accessories; Tweezers; Domestic \& } \\
\text { household items; Escutcheons; Weapons; } \\
\text { Equestrian equipment; ?Book page clip; Fittings } \\
\text { \& parts; Manufacturing debris }\end{array}$ \\
\hline Literacy & Items associated with literacy & $\begin{array}{l}\text { Writing implements; Writing accessories; } \\
\text { Inscribed artefacts (Latin, Runes, Lombardic) }\end{array}$ \\
\hline $\begin{array}{l}\text { Recycling \& } \\
\text { reuse }\end{array}$ & $\begin{array}{l}\text { Modified artefacts of Roman } \\
\& \text { early medieval date }\end{array}$ & $\begin{array}{l}\text { Recycled pottery; Coins; Vessels; Armlets; } \\
\text { Bracelet; Gaming piece; Querns; Loomweight; } \\
\text { Stone; Building material \& tiles; ?Drinking horn }\end{array}$ \\
\hline Ritual & $\begin{array}{l}\text { Material culture interpreted as } \\
\text { representing or imbued with } \\
\text { ritualistic meaning }\end{array}$ & $\begin{array}{l}\text { "Special deposits»; Items portraying ?Christian } \\
\text { references; Amulets; ?Thor's hammer pendant; } \\
\text { ?Norse bells }\end{array}$ \\
\hline Burial \& funerary & $\begin{array}{l}\text { Material culture potentially } \\
\text { evidencing or representing } \\
\text { burial \& funerary practices } \\
\text { (primary \& secondary } \\
\text { contexts) }\end{array}$ & $\begin{array}{l}\text { Primary evidence: Grave goods from settlement } \\
\text { burials (i.e. knives, beads, pins, combs, Roman } \\
\text { coins etc.) } \\
\text { Secondary evidence: Disarticulated human bone; } \\
\text { Urn sherds; Funerary type bowls; Hanging bowl } \\
\text { escutcheons; Salin Style II fittings \& mounts }\end{array}$ \\
\hline
\end{tabular}

Table 3. Consumption activities evidenced at the settlements.

The analysis demonstrates that domestic/household, manufacturing, utilitarian and agricultural/cultivation activities were predominantly undertaken at the settlements (Figure 3). The occurrence of these activities at rural settlements can arguably be expected. The tasks, preferences and priorities which engaged settlement households are evidenced by activities ranging from food preparation to laundering, as well as choices concerning dress, personal adornment and grooming habits. Agricultural and manufacturing activities - including textile, metal, bone and wood working - were supported by utilitarian tasks and undertaken to varying degrees at the settlements, from household levels to the production of surpluses, which could have been exchanged or traded.

The identification of other consumption activities, in addition to the above, emphasises the social and economic complexities of many rural settlements. For instance, hunting and fishing provided the opportunity for sport as well as the obtainment of food and animal materials such as hides. The recycling of artefacts, predominantly objects of Roman date, also took place. Such modified items range from spindlewhorls and pendants to gaming counters, the latter evidencing leisurely pursuits. Also found are objects that may have been imbued with ritualistic significance, such as items likely portraying Christian allusions and artefacts possibly associated with burial/funerary rites, including funerary type bowls. However, it is acknowledged that other artefacts likely to have been attributed such devotional qualities in the early medieval period remain unidentifiable to the modern interpreter of the archaeological record. Warfare, equestrian and literate 
endeavours particularly point towards settlement social structures, encompassing occupations, pursuits and skills which denote levels of rank and/or prosperity. Degrees of status and affluence are further supported by evidence for prestige consumption and access to such goods, as well as portable wealth in the form of coins which highlight trade/ exchange activities and monetary circulation within some rural settlements.

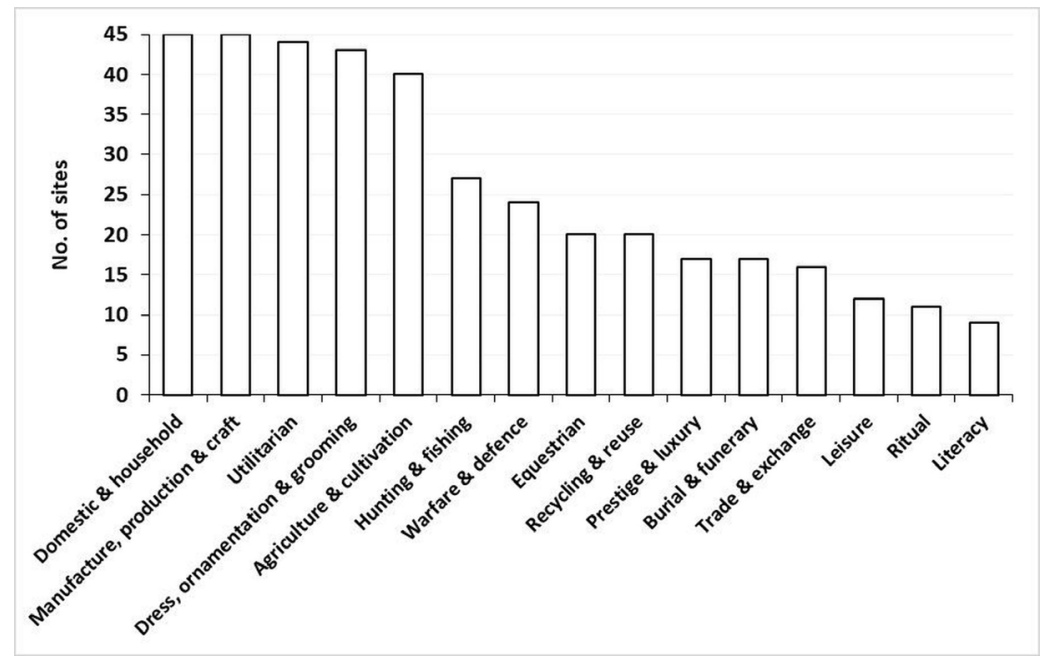

FIGURE 3. Consumption activities occurrence at the settlements.

The consumption diversity of many rural settlements demonstrates the socio-economic complexities of such communities, with the undertaking of various activities beyond the domestic, utilitarian, manufacturing and agricultural spheres that may be traditionally associated with rural life.

\section{RURAL SETTLEMENTS: NETWORKS AND REACH}

The provenance and distribution of material culture demonstrates rural settlement participation in trade/exchange, travel and communication networks of various reach. The analysis encompasses object provenance as recorded in the consulted publications, which vary in detail from specific localities (i.e. York), to broader areas (i.e. Yorkshire), or regions (i.e. Northern England). However, all the information was collated in order to maximise the data for analysis ${ }^{57}$. In addition to variations in the provenance descriptions provided, the challenges of determining modes of transference with confidence in the archaeological record should be noted. For example, as well as exchange and commercial transactions, material culture could have reached the settlements through a range of

57 Lewis, Pattern and process, p. 28-30, 173-207. 
circumstances such as gift-giving, booty, migration, displacement (i.e. slaves) or travel events from tourism to religious or political missions ${ }^{58}$.

The settlements produce artefacts from local and regional as well as interregional and imported sources (Table 4). This shows rural communities participated to differing levels in economic, travel and communication networks of various reach, which supported the movement and accessibility of goods. Diverse artefacts derive from these sources, from utilitarian and manufacturing objects to domestic/household and personal adornment items ${ }^{59}$.

\begin{tabular}{|c|c|c|}
\hline \multirow[b]{2}{*}{ Material culture } & \multicolumn{2}{|l|}{ Provenance \& examples } \\
\hline & $\begin{array}{l}\text { Local \& (inter-) regional } \\
\text { provenance }\end{array}$ & Imported \\
\hline \multirow{2}{*}{ Coins } & \multirow{2}{*}{ Sceattas; Stycas; Pennies } & Continent: Sceattas \\
\hline & & Central Asia: Kufic dirham imitation \\
\hline \multirow{2}{*}{ Pottery } & \multirow{2}{*}{$\begin{array}{l}\text { Charnwood types; Maxey types; } \\
\text { Ipswich; Thetford types; St Neots; } \\
\text { Stamford }\end{array}$} & $\begin{array}{l}\text { Continent: Merovingian; Frankish; } \\
\text { Northern French; Rhenish; Tating; } \\
\text { Badorf }\end{array}$ \\
\hline & & $\begin{array}{ll}\text { Egyptian/Eastern } & \text { Mediterranean: } \\
\text { Coptic; Biv amphora } & \\
\end{array}$ \\
\hline \multirow{2}{*}{ Stone artefacts } & \multirow{2}{*}{$\begin{array}{l}\text { Millstone Grit; Greensand; } \\
\text { Corallian; Chalk; Limestone; } \\
\text { Sandstone types; Staddon Grit }\end{array}$} & $\begin{array}{l}\text { Continent: Niedermendig lava; French } \\
\text { Aubigny-type; ?Andernach tuff }\end{array}$ \\
\hline & & Scandinavia: ragstone \\
\hline Beads & Jet; Glass & Continent: Glass \\
\hline \multirow{3}{*}{ Gemstones } & \multirow{3}{*}{ Jet } & Scandinavia/Baltic: Amber \\
\hline & & Bohemia/Sri Lanka: Garnet \\
\hline & & India/Sri Lanka: Amethyst \\
\hline Brooches & $\begin{array}{l}\text { Disc; Applied disc; Annular; } \\
\text { ?Equal-armed }\end{array}$ & $\begin{array}{l}\text { Continent: Frankish; ?«Anglian»; } \\
\text { ?Caterpillar; ?Equal-armed }\end{array}$ \\
\hline Pins & Hamwic types & Continent: ?Ross Type V \\
\hline Strap ends & $\begin{array}{l}\text { Hamwic Type A; Oval ears \& } \\
\text { lunate incised decoration; Inlaid } \\
\text { silver wire ornamented }\end{array}$ & \\
\hline Glass artefacts & Beads & $\begin{array}{l}\text { Continent: Vessels; Beakers; Inkwells; } \\
\text { Beads; ?Window glass; Undiagnostic }\end{array}$ \\
\hline $\begin{array}{l}\text { Anglo-Scandinavian } \\
\& \text { Scandinavian } \\
\text { artefacts }\end{array}$ & $\begin{array}{l}\text { Jewellery \& dress accessories } \\
\text { (i.e. Borre, Jelling, Trefoil styles); } \\
\text { ?Thor's hammer pendant; Tools } \\
\text { \& implements (i.e. strike-a- } \\
\text { lights, spoon augers); Equestrian } \\
\text { equipment (i.e. Ringerike style } \\
\text { ?stirrup mount); ?Norse bells }\end{array}$ & $\begin{array}{l}\text { Scandinavian world: Tools \& } \\
\text { implements (i.e. stone hones); Jewellery } \\
\text { \& dress accessories (i.e. Borre, Jelling, } \\
\text { Trefoil styles); Equestrian equipment } \\
\text { (i.e. likely stirrup, harness \& bridal } \\
\text { set); ?Hiberno-Viking square stud; } \\
\text { ?Valsgärde bowl }\end{array}$ \\
\hline
\end{tabular}

TABLE 4. Material culture provenance: examples from the settlements.

58 McCormick, Michael. Origins of the European economy: Communications and commerce AD300900. Cambridge: Cambridge University Press, 2002, p. 271-274, 281, 607; Brookes, Economics and social change, p. 18-21.

59 Lewis, Pattern and process, Appendix 6, https://www.barpublishing.com/additional-downloads.html. 
Artefacts of local provenance are most commonly identified at the sites throughout the period, with the production of such items highlighted by the various manufacturing activities taking place at the settlements ${ }^{60}$. General increases over time in the consumption and acquisition of locally and (inter-) regionally sourced goods is apparent at the rural settlements, for example mass-produced pottery such as Ipswich, Thetford-type and St Neots wares. This reflects the development of agricultural and industrial output and market systems in early medieval England, particularly from the c. early $8^{\text {th }}$ century on ${ }^{61}$.

Imported artefacts also reveal an apparent chronological trend. Settlements occupied during the Early Anglo-Saxon period and into the Middle Anglo-Saxon centuries produce the greatest quantity and diversity of imported goods from widespread sources. The various imports include: pottery from the Continent, the eastern Mediterranean including Egypt and possibly Asia Minor; worked stone (most commonly Niedermendig/ Mayen lava) from Continental regions such as the Rhineland and the Low Countries; personal items such as glass beads produced on the Continent; amber sourced from the Baltic/Nordic regions; garnet from Bohemia or Sri Lanka; and amethyst of Sri Lankan or Indian provenance. From the $c .7^{\text {th }}$ century, Continental sceattas are found at some sites, mirroring the development of currency in the Anglo-Saxon kingdoms ${ }^{62}$.

These findings are significant, demonstrating that rural sites obtained, consumed and had access to an array of imports via exchange/trade, travel and communications networks before the establishment of other major settlement types, such as emporia which supported and facilitated specialised production as well as trade from the later $7^{\text {th }}$ century ${ }^{63}$. It can be surmised that some of the goods, such as amethyst or items incorporating garnet, were considered exceptional at least partially due to their exotic provenance. This likely highlights circumstances of social differentiation within rural settlements producing such items.

It is also of interest that, in contrast to the apparent egalitarian character and organisation of settlements of Early Anglo-Saxon date as discussed above, many of these sites produce various imported goods in addition to other significant material culture, such as likely prestige items and glass vessels, which instead point towards hierarchical differentiations. This seeming contrast between the morphology and material culture of rural settlements dating to the earlier Anglo-Saxon centuries has implications for the study of settlement hierarchy and merits future investigation.

The range and quantity of imports decreases from the $c .9^{\text {th }}$ century and moving into the Late Anglo-Saxon centuries, coinciding with the rise of productive output in

60 Lewis, Pattern and process, p. 136-148, 173-174.

61 i.e. Wickнам, Framing the early Middle Ages, p. 696, 808; Brookes, Economics and social change, p. 32 .

62 Lewis, Pattern and process, p. 205-207, 236, 239, 246-249.

63 i.e. Anderton, Mike (ed.). Anglo-Saxon trading centres: Beyond the emporia. Glasgow: Cruithne Press, 1999; Loveluck, Christopher \& Tys, Dries. "Coastal societies, exchange, and identity along the channel and the North Sea shores of Europe, AD600-1000». Journal of Marine Archaeology, 2006, 1, p. 140-169; Hodges, Dark Age economics. 
early medieval England ${ }^{64}$. The source areas of the imports also contracts to western and northern Europe, with the exception of a Kufic dirham (coin) imitation of central Asian origin $^{65}$. Imported gemstones are not found in later centuries, however goods which remain in demand include Niedermendig lava querns and pottery such as northern French and Rhenish wares. Imported Scandinavian goods, notably Norwegian ragstone hones, and Anglo-Scandinavian type artefacts become prevalent, in contrast to earlier centuries. The Anglo-Scandinavian objects are diverse and include jewellery, equestrian equipment, weapons and utilitarian items. It is likely that many of the Anglo-Scandinavian items were produced in England, for example in major centres such as Lincoln and York within the «Danelaw». The Danish/Scandinavian controlled Danelaw kingdom was founded in the later $9^{\text {th }}$ century and encompassed north, east and midlands England. However, some of the Anglo-Scandinavian goods may have been imports, representing cultural exchange and arriving at the settlements by means such as migration, travel and trade.

Changes over time in the patterns, types and amounts of imports present at the rural settlements reflects various economic/commercial, political and social transformations in early medieval England. This includes the introduction of large-scale production and specialisations as well as circumstances such as the Viking/Scandinavian raids and migrations from the $9^{\text {th }}$ century, which all influenced the supply, demand, accessibility and circulation of goods.

Overall, analysis of material culture provenance emphasises that many rural settlements were economically and socially complex, with involvement in producing, procuring and consuming goods and commodities and participating in the economic, politi$\mathrm{cal}$ and social systems of early medieval England. The socio-economic complexities and reach of rural settlements bears relevance for the study of settlement hierarchy. Notably, the range of material culture from sites of Early Anglo-Saxon date suggests greater social sophistications than the apparent egalitarian morphology exhibited by the settlements. Also, it must be considered that the exploitation of various commercial and travel networks would contribute to some settlements functioning as focal centres of local or (inter-) regional importance, adding to the status of such communities.

\section{SetTlement HiERARCHY}

The findings discussed in this paper involving the multifaceted character of many rural settlements has further emphasised the need for a reassessment of settlement hierarchy in early medieval England, as well as some of the challenges inherent in this task.

Significantly, many rural settlements, as evidenced by material culture as well as consumption and economic patterns, were complex communities which undertook and facilitated a range of activities and roles. This emphasises that a variety of functions and portable objects often associated with other settlement types are not atypical of rural sites. It also strongly supports the existence of social and settlement status distinctions

64 Lewis, Pattern and process, p. 205-207, 243-246.

65 Rogerson, Andrew. A Late Neolithic, Saxon and medieval site at Middle Harling, Norfolk. East Anglian Archaeology 74. London: British Museum; Norfolk: Field Archaeology Division, Norfolk Museums Service, 1995, p. 52-53. 
amongst rural communities. Given this and the various functions and roles performed by some rural settlements, from market centres to provincial and territorial foci, rural sites cannot feasibly be considered as a hierarchically homogeneous settlement group.

As the diversities and complexities of settlement types in early medieval England continue to be illuminated by the increasing amount of archaeological evidence available for research, further re-evaluation is required of simplistic hierarchical models, including greater recognition of the broad class of «rural settlements» as diverse communities of varied social, economic and hierarchical sophistications ${ }^{66}$. To address this, a new model of settlement hierarchy is proposed here (Figure 4). The model has been produced following consideration of the relevant scholarship, challenges inherent in the study and the rural settlement research presented. The model is comprehensive, endeavouring to encompass the broad range of settlement types and societal structures (i.e. kin-orientated, ranked, stratified etc.) which chronologically span the early medieval period in England. It focuses on political, economic and social authority as well as the functions and roles of settlements as indicators of hierarchy and significance. Settlement type examples have been provided for the seven hierarchical tiers proposed, some of which fall into more than one category, reflecting the overlapping functions and diverse character of settlement types.

SETTLEMENT HIERARCHY

1. Royal authorities
permanent and itinerant centres of royal power and prerogative

\section{Central foci authorities}

settlements undertaking a variety of administrative/judicial/ecclesiastical/defence/

economic (commerce, agricultural, production, industrial etc.) functions

\section{Elite settlements}

privileged and/or exceptionally wealthy centres, undertaking aristocratic, ecclesiastical

or other role(s) such as administration, production or trade

\section{Central foci}

settlements undertaking a selection of administrative/judicial/ecclesiastical/defence/

economic (commerce, agricultural, production, industrial etc.) functions

\section{Limited production/distribution settlements}

settlements supporting a limited variety of functions or specialisations, likely including

smaller-scale production, surplus and/or trade and exchange activities

\section{Limited multi-functional settlements}

settlements undertaking limited production, surplus and/or trade and exchange activities, with no apparent specialisations

7. Non-complex settlements

settlements supporting either none or minimal functions beyond the household sphere
Examples (permanent/itinerant

'great hall' complexes; palaces; royal estates; vills

burh towns/settlements; ecclesiastical/minster settlements; emporia; major towns; manorial settlements; provincial capitals/centres

ecclesiastical institutions/settlements; estate centres; manorial complexes/settlements; noble residences

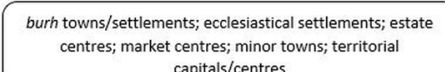
capitals/centres

farmsteads; 'productive' sites; villages

farmsteads; hamlets; homesteads; villages

hamlets; homesteads

Figure 4. Settlement hierarchy in early medieval England.

66 i.e. UlmschneIdeR, «Settlement hierarchy», p. 156-157. 
The more conventional view of royalty at the apex of hierarchy is retained here, with royal centres (permanent and itinerant) and estates determined as the highest-ranking settlement types. It is contended that royal prerogative warranted the power to oversee any community through various channels including legislation, taxes and duties, and that such all-pervasive authority represents the epitome of significance and status.

Below royal centres are settlements termed «central foci authorities». It is argued from a role-related perspective that such settlements supported a greater range of functions, occupations and attractions which, when combined, constitute authority. As a result of controlling a wide range of activities (i.e. administrative, judicial, economic, ecclesiastical, defence etc.), these settlements provided an essential focal point in the landscape for the populace and the political, social and economic frameworks of early medieval England. The scope of functions undertaken at settlements and evidence for the utilisation of trade/exchange, travel and communication networks supports the identification of central foci, for instance principal towns, emporia and rural settlements serving as provincial capitals/centres. In order to facilitate a greater range of functions and trade/exchange links, such settlements would necessitate a greater socially - and therefore hierarchically - diverse permanent and (semi-) transient population than other communities less varied in terms of activities or consumption. The populace would be essential to undertake, provision and engage in the spectrum of occupations, specialisations and goods and services available at the settlements, with visitors also attracted to participate in such endeavours.

Following are elite secular and ecclesiastical settlements, that may potentially be interpreted as such due to their aristocratic, privileged, exceptionally wealthy and/or economically successful character. Examples are certain monastic institutions and noble residences including manorial settlements and complexes, some of which engaged in conspicuous consumption and/or commercial activities such as manufacture and trade. The manifestation of power held by the elite classes and often associated prosperity ensures the high status character of such settlements, along with the impact of authoritative endeavours such as managing lands or estates and organising production (i.e. agriculture, manufacture etc.). In comparison, it is reasoned that central foci authorities harnessed the means to offer a greater amalgamated scope of functions, output, prospective opportunities and access to various networks. This culminated in an overall greater influence with the populace, and hence authority, than that of elite settlements. Moreover, as the evidence analysed concerning rural settlements in this paper has further developed, it can be concluded that people of status or considerable wealth - likely including elite personages - were associated with, or resided within, a range of settlements.

Next considered are smaller central foci settlements, which facilitated on a lesser scale various combinations of the activities, livelihoods, advantages and accessibility to exchange, trade and communication networks offered by larger central foci authorities, as well as some elite centres. Examples include a range of urban and rural settlements such as small towns, market centres, burbs (fortified settlements or towns) and territorial capitals/centres. 
Following are settlements which supported a limited variety of functions or specialisations. This commonly included smaller-scale production, surplus and/or participation to a degree in exchange, trade or similar economic activities. Examples include "productive» sites and other rural settlements such as villages and (grouped) farmsteads.

Below are considered settlements with no apparent specialisations that were engaged in limited production, possibly surplus and/or trade and exchange activities, including rural settlements such as hamlets.

Finally, settlements which either did not undertake or supported only minimal functions outside of the household sphere are considered as lowest ranking, such as (grouped) homesteads.

The settlements of study provide varied examples of the hierarchical model, excepting the top two tiers (Figure 4; Appendix). Staunch Meadow (Brandon) can be considered an elite settlement (third-tier settlement). Mucking in Essex, Carlton Colville in Suffolk and West Fen Road in Cambridgeshire are probable examples of smaller central foci settlements (fourth-tier settlement). Fifth- and sixth-tier settlements are most commonly represented in the dataset, ranging from Riby Cross Roads in Lincolnshire and Orton Hall Farm in Cambridgeshire, to Pennyland in Buckinghamshire as well as Market Lavington and Collingbourne Ducis, both in Wiltshire. Seventh-tier settlements are also represented, for example by Goch Way, Hampshire.

The proposed hierarchy model with settlement type examples is intended as a useful framework for hierarchical research moving forward, as archaeological evidence available for the study of the material culture, consumption and economic patterns of settlements in early medieval England continues to increase. The wealth of information such data can provide is demonstrated by the study of rural settlements presented, which reveals the multifaceted character and social complexities of many rural communities. The analysis also highlights some of the challenges of hierarchical studies, particularly that different settlement types supported many of the same functions, such as production and commercial services. The findings also contribute to debate concerning the interpretation of settlement status, particularly the need for a reassessment of «high status», as degrees of prosperity and rank as well as population diversification appear to have been more varied in a greater range of settlements than commonly thought.

\section{Discussion}

This paper contributes to the study of settlement hierarchy in early medieval England, addressing some of the challenges through a focus on the material culture of rural settlements, which are often overlooked in favour of sites such as ecclesiastical centres, emporia or towns. By analysing material culture evidence, it is established that many rural settlements were inherently complex communities, embedded in the political, social and economic systems of early medieval England.

The diversity of material culture indicates the existence of social distinctions within rural settlements, encompassing differing levels of status and affluence. This may be seen 
from the strong kin-based societal ties of the Early Anglo-Saxon period, to the growth of a ranked society with increasingly complex hierarchical structures, and the progressively stratified organisation of society in the Late Anglo-Saxon period. This evidence is supported by patterns of consumption, which reveal that many settlements undertook and facilitated a variety of functions beyond the household sphere and agricultural-related tasks that may conventionally be associated with rural communities. Material culture provenance shows that an array of goods from widespread sources were present at rural sites, as a result of various circumstances such as exchange, trade, migration and travel. This highlights settlement participation in the economic, travel and communication networks of early medieval England and supports the identification of rural settlements that may have served various roles, ranging from central foci to estate and market centres.

Significantly, material culture evidence demonstrates the socio-economic sophistication of settlements of Early Anglo-Saxon date and points towards hierarchical differentiations within these communities. This is seemingly in contrast to the arrangements and architecture of the rural settlements which are generally interpreted as broadly egalitarian in character. Evidence further shows that multifaceted settlements were not atypical prior to the Middle Anglo-Saxon centuries, the period from which society and settlements in early medieval England are more commonly considered complex socio-economic entities $^{67}$. These findings emphasise the difficulties of defining settlement status and indicate that aspects of the prevailing views likely require some revision, for example the designation of the $7^{\text {th }}$ century as the watershed moment for the emergence and apparent proliferation of elite settlements in the landscape.

Moving forward, studies of hierarchy will continue to benefit from cross-comparative analyses of evidence illuminating the forms, functions and character of early medieval settlement types. Assessment of the types, range and provenance of material culture collections as well as botanical and faunal assemblages have the strong potential to reveal socio-economic patterns within - as well as between - communities, from evidence of consumption, diet, supply and demand to production output and agrarian processes. Socio-economic aspects of different settlement types may also be illustrated by the examination of settlement morphology and analysis of material culture and environmental evidence in terms of site distributional patterns (the recorded contexts/locations of archaeological evidence at a site). These methodologies can highlight evidence including architectural diversity, in terms of building forms and functions, or possible settlement «zoning» by characteristics such as activities or occupations. Hierarchical diversity within communities is increasingly being demonstrated by studies which employ such approaches ${ }^{68}$.

67 i.e. Hansen, Inge Lyse \& Wickham, Christopher (eds.). The long eighth century: Production, distribution and demand. Leiden: Brill, 2000, p. Ix; Rippon, Stephen. «Landscape change during the «long eighth century» in southern England». In: Higham, Nicholas J. \& Ryan, Martin J. (eds.). The landscape archaeology of Anglo-Saxon England. Woodbridge: Boydell Press, 2010, p. 39-64, p. 44-45.

68 i.e. Loveluck, Northwest Europe in the early Middle Ages, i.e. p. 98-99, 205-206; Lewis, Pattern and process, esp. p. 219-228. 
This research contributes to the study of settlement hierarchy and areas within the field that merit further investigation. It has shown that the broad definition of «rural settlements» encompasses a range of often complex, diverse and in some cases clearly prosperous communities, emphasising that prevailing conceptions of «high» and «low» status settlements requires reinterpretation. Addressing this is a proposed new model of settlement hierarchy and a call for further cross-comparative approaches to be undertaken in the discipline.

Appendix

The settlements of study.

\begin{tabular}{|c|c|}
\hline $\begin{array}{l}\text { Settlements of study } \\
\text { (alphabetical) }\end{array}$ & References (select) \\
\hline $\begin{array}{l}\text { Abingdon (Audlett Drive), } \\
\text { Oxfordshire (formally } \\
\text { Berkshire) }\end{array}$ & $\begin{array}{l}\text { KeEvil, Graham D. «An Anglo-Saxon site at Audlett Drive, Abingdon, } \\
\text { Oxfordshire». Oxoniensia, 1992, 57, p. 55-79. }\end{array}$ \\
\hline $\begin{array}{l}\text { Barton Court Farm, } \\
\text { Oxfordshire (formally } \\
\text { Berkshire) }\end{array}$ & $\begin{array}{l}\text { Miles, David (ed.). Archaeology at Barton Court Farm Abingdon, Oxon: } \\
\text { An investigation of the Neolithic, Iron Age, Romano-British, and Saxon } \\
\text { settlements. Oxford Archaeological Unit Report 3; CBA Research } \\
\text { Report 50. Oxford: Oxford Archaeological Unit \& Council for British } \\
\text { Archaeology, } 1986 \text {. }\end{array}$ \\
\hline $\begin{array}{l}\text { Bishopstone, } \\
\text { East Sussex }\end{array}$ & $\begin{array}{l}\text { Bell, Martin. "Excavations at Bishopstone». Sussex Archaeological } \\
\text { Collections, 1977, } 115 \text {. } \\
\text { THOMAS, Gabor. The later Anglo-Saxon settlement at Bishopstone: A } \\
\text { downland manor in the making. CBA Research Report 163. York: } \\
\text { Council for British Archaeology, } 2010 \text {. }\end{array}$ \\
\hline $\begin{array}{l}\text { Brandon Road, Thetford, } \\
\text { Norfolk }\end{array}$ & $\begin{array}{l}\text { Atкins, Rob \& Connor, Aileen. Farmers and ironsmiths: Prehistoric, } \\
\text { Roman and Anglo-Saxon settlement beside Brandon Road, Thetford, } \\
\text { Norfolk. East Anglian Archaeology 134. Bar Hill: Oxford Archaeology } \\
\text { East, } 2010 \text {. }\end{array}$ \\
\hline $\begin{array}{l}\text { Carlton Colville } \\
\text { (Bloodmoor Hill), } \\
\text { Suffolk }\end{array}$ & $\begin{array}{l}\text { Lucy, Sam; Tipper, Jess \& Dickens, Alison. The Anglo-Saxon settlement } \\
\text { and cemetery at Bloodmoor Hill, Carlton Colville, Suffolk. East Anglian } \\
\text { Archaeology 131. Cambridge: Cambridge Archaeological Unit, } 2009 .\end{array}$ \\
\hline $\begin{array}{l}\text { Catholme, } \\
\text { Staffordshire }\end{array}$ & $\begin{array}{l}\text { LosCo-Bradley, Stuart \& KinsLeY, Gavin. Catholme: An Anglo-Saxon } \\
\text { settlement on the Trent gravels in Staffordshire. Nottingham: Department } \\
\text { of Archaeology, University of Nottingham, } 2002 \text {. }\end{array}$ \\
\hline $\begin{array}{l}\text { Chalton, } \\
\text { Hampshire }\end{array}$ & $\begin{array}{l}\text { Addyman, Peter V.; Leigh, David J. \& Hughes, Michael J. «Anglo- } \\
\text { Saxon houses at Chalton, Hampshire». Medieval Archaeology, 1972, 16, } \\
\text { p. 13-33. } \\
\text { AdDyman, Peter V. «The Anglo-Saxon village at Chalton, Hampshire: } \\
\text { Second interim report». Medieval Archaeology, 1973, 17, p. 1-25. } \\
\text { CHAMPION, T. "Chalton». Current Archaeology, 1977, } 59 \text { vol. V/12, p. } \\
\text { 364-369. }\end{array}$ \\
\hline
\end{tabular}




\begin{tabular}{|c|c|}
\hline $\begin{array}{l}\text { Settlements of study } \\
\text { (alphabetical) }\end{array}$ & References (select) \\
\hline $\begin{array}{l}\text { Collingbourne Ducis } \\
\text { (Cadley Road), } \\
\text { Wiltshire }\end{array}$ & $\begin{array}{l}\text { PINE, Jo. "The excavation of the Saxon settlement at Cadley Road, } \\
\text { Collingbourne Ducis, Wiltshire». Wiltshire Archaeological and Natural } \\
\text { History Magazine, 2001, 94, p. 88-117. }\end{array}$ \\
\hline $\begin{array}{l}\text { Cottam, } \\
\text { East Yorkshire }\end{array}$ & $\begin{array}{l}\text { Richards, Julian D. "Cottam: An Anglian and Anglo-Scandinavian } \\
\text { settlement on the Yorkshire Wolds". Archaeological Journal, 1999, 156, } \\
\text { p. } 1-110 \text {. }\end{array}$ \\
\hline $\begin{array}{l}\text { Cottenham (Lordship } \\
\text { Lane), } \\
\text { Cambridgeshire }\end{array}$ & $\begin{array}{l}\text { Mortimer, Richard \& Hall, David N. "Village development and } \\
\text { ceramic sequence: The Middle and Late Saxon village at Lordship Lane, } \\
\text { Cottenham, Cambridgeshire». Proceedings of the Cambridge Antiquarian } \\
\text { Society, 2000, 89, p. 5-33. }\end{array}$ \\
\hline $\begin{array}{l}\text { Cowdery's Down, } \\
\text { Hampshire }\end{array}$ & $\begin{array}{l}\text { Millett, Martin \& James, Simon. «Excavations at Cowdery’s Down, } \\
\text { Basingstoke, Hampshire, 1978-81». Archaeological Journal, 1983, 140, } \\
\text { p. 151-279. }\end{array}$ \\
\hline $\begin{array}{l}\text { Fordham (Hillside } \\
\text { Meadow), } \\
\text { Cambridgeshire }\end{array}$ & $\begin{array}{l}\text { Patrick, Catharine \& RátKaI, Stephanie. «Hillside Meadow, } \\
\text { Fordham». In: Cuttler, Richard; MarTin-BaCON, Helen; NICHOL, } \\
\text { Kirsty; Patrick, Catharine; PerRIN, Rob; RátKaI, Stephanie; SMITH, } \\
\text { Martin \& Williams, Josh. Five sites in Cambridgeshire: Excavations at } \\
\text { Woodhurst, Fordham, Soham, Buckden and St Neots, 1998-2002. BAR } \\
\text { British Series 528. Oxford: Archaeopress, 2011, p. 41-122. }\end{array}$ \\
\hline $\begin{array}{l}\text { Foxholes Farm, } \\
\text { Hertfordshire }\end{array}$ & $\begin{array}{l}\text { PARTRIDGE, Clive. Foxholes Farm: A multi-period gravel site. Hertford: } \\
\text { Hertfordshire Archaeological Trust, } 1989 .\end{array}$ \\
\hline $\begin{array}{l}\text { Goch Way, } \\
\text { Hampshire }\end{array}$ & $\begin{array}{l}\text { WRIGHT, James. «Excavation of Early Saxon settlement and Mesolithic } \\
\text { activity at Goch Way, near Charlton, Andover». Proceedings of the } \\
\text { Hampshire Field Club Archaeological Society, 2004, 59, p. 116-138. }\end{array}$ \\
\hline $\begin{array}{l}\text { Godmanchester, } \\
\text { Cambridgeshire }\end{array}$ & $\begin{array}{l}\text { GIBSON, C. with MurRaY, J. "An Anglo-Saxon settlement at } \\
\text { Godmanchester, Cambridgeshire». In: Griffiths, David W..; } \\
\text { ReYNOLDS, Andrew \& Semple, Sarah (eds.). Boundaries in Early } \\
\text { Medieval Britain. Anglo-Saxon Studies in Archaeology and History } 12 . \\
\text { Oxford: Oxford University School of Archaeology, 2003, p. 137-217. }\end{array}$ \\
\hline $\begin{array}{l}\text { Goltho, } \\
\text { Lincolnshire }\end{array}$ & $\begin{array}{l}\text { BERESFORD, Guy. Goltho: The development of an early medieval manor } c \text {. } \\
\text { 850-1150. London: Historic Buildings and Monuments Commission } \\
\text { for England, } 1987 \text {. }\end{array}$ \\
\hline $\begin{array}{l}\text { Heybridge, } \\
\text { Essex }\end{array}$ & $\begin{array}{l}\text { DrurY, Paul J., \& Wickenden, N. P. "An Early Saxon settlement } \\
\text { within the Romano-British small town at Heybridge, Essex». Medieval } \\
\text { Archaeology, 1982, 26, p. 1-39. }\end{array}$ \\
\hline $\begin{array}{l}\text { Kilverstone, } \\
\text { Norfolk }\end{array}$ & $\begin{array}{l}\text { GaRrow, Duncan; LuCY, Sam \& GIBSON, David. Excavations at } \\
\text { Kilverstone, Norfolk: An episodic landscape history. East Anglian } \\
\text { Archaeology 113. Cambridge: Cambridge Archaeological Unit, } 2006 .\end{array}$ \\
\hline $\begin{array}{l}\text { Lechlade, } \\
\text { Gloucestershire }\end{array}$ & $\begin{array}{l}\text { Bateman, Clifford; ENRIGHT, Dawn \& OAKLEY, Niall. «Prehistoric and } \\
\text { Anglo-Saxon settlements to the rear of Sherborne House, Lechlade: } \\
\text { Excavations in 1997». Transactions of the Bristol and Gloucestershire } \\
\text { Archaeological Society, 2003, 121, p. 23-96. } \\
\text { KenYon, David \& CollarD, Mark. «Anglo-Saxon and medieval remains } \\
\text { at Kent Place, Sherborne Street: Excavations in 2000». Transactions of } \\
\text { the Bristol and Gloucestershire Archaeological Society, 2004, 122, p. } 117- \\
126 .\end{array}$ \\
\hline
\end{tabular}




\begin{tabular}{|c|c|}
\hline $\begin{array}{l}\text { Settlements of study } \\
\text { (alphabetical) }\end{array}$ & References (select) \\
\hline $\begin{array}{l}\text { Market Lavington, } \\
\text { Wiltshire }\end{array}$ & $\begin{array}{l}\text { Williams, Phillip \& Newman, Richard. Market Lavington, Wiltshire, } \\
\text { an Anglo-Saxon cemetery and settlement: Excavations at Grove Farm, } \\
\text { 1986-90. Wessex Archaeology report 19. Salisbury: Wessex Archaeology } \\
\text { Ltd., 2006. }\end{array}$ \\
\hline $\begin{array}{l}\text { Mawgan Porth, } \\
\text { Cornwall }\end{array}$ & 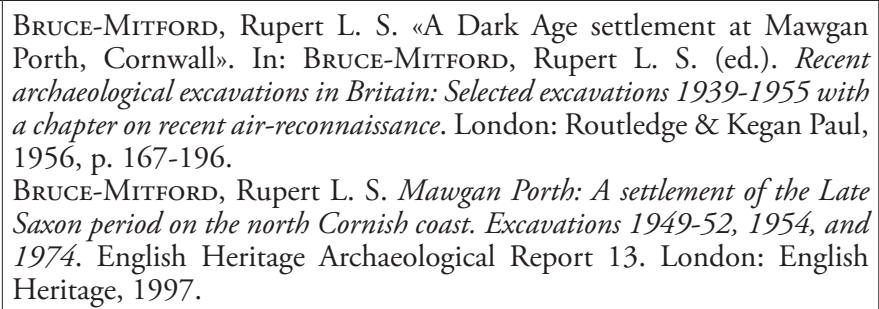 \\
\hline $\begin{array}{l}\text { Maxey, } \\
\text { Cambridgeshire (formally } \\
\text { Northamptonshire) }\end{array}$ & $\begin{array}{l}\text { Addyman, Peter V. "A Dark Age settlement at Maxey, } \\
\text { Northamptonshire». Medieval Archaeology, 1964, 8, p. 20-73. }\end{array}$ \\
\hline $\begin{array}{l}\text { Melford Meadows, } \\
\text { Brettenham, } \\
\text { Norfolk }\end{array}$ & $\begin{array}{l}\text { MudD, Andrew. Excavations at Melford Meadows, Brettenham, 1994: } \\
\text { Romano-British and Early Saxon occupations. East Anglian Archaeology } \\
\text { 99. Oxford: Oxford Archaeological Unit, 2002. }\end{array}$ \\
\hline $\begin{array}{l}\text { Middle Harling, } \\
\text { Norfolk }\end{array}$ & $\begin{array}{l}\text { Rogerson, Andrew. A Late Neolithic, Saxon and medieval site at Middle } \\
\text { Harling, Norfolk. East Anglian Archaeology } 74 \text {. London: British } \\
\text { Museum; Norfolk: Field Archaeology Division, Norfolk Museums } \\
\text { Service, } 1995 \text {. }\end{array}$ \\
\hline $\begin{array}{l}\text { Mucking, } \\
\text { Essex }\end{array}$ & $\begin{array}{l}\text { Hamerow, Helena. Excavations at Mucking Volume 2: The Anglo-Saxon } \\
\text { settlement. London: English Heritage, } 1993 \text {. }\end{array}$ \\
\hline $\begin{array}{l}\text { Orsett Cock, Thurrock, } \\
\text { Essex }\end{array}$ & $\begin{array}{l}\text { CARTER, G. A. Excavations at the Orsett 'Cock' Enclosure, Essex, } 1976 . \\
\text { East Anglian Archaeology 86. Chelmsford: Essex County Council, } \\
1998 . \\
\text { Milton, Brian. «Excavations at Barrington's Farm, Orsett Cock, } \\
\text { Thurrock, Essex 1983». Essex Archaeology and History, 1987, 18, p. 16- } \\
\text { 33. } \\
\text { Toller, H. S. «An interim report on the excavation of the Orsett «Cock» } \\
\text { Enclosure, Essex: 1976-79». Britannia, 1980, 11, p. 35-42. }\end{array}$ \\
\hline $\begin{array}{l}\text { Orton Hall Farm, } \\
\text { Cambridgeshire }\end{array}$ & $\begin{array}{l}\text { MaскRETH, Donald. Orton Hall Farm: A Roman and Early Anglo-Saxon } \\
\text { farmstead. East Anglian Archaeology } 76 \text {. Manchester: Nene Valley } \\
\text { Archaeological Trust, } 1996 .\end{array}$ \\
\hline $\begin{array}{l}\text { Pennyland, } \\
\text { Buckinghamshire }\end{array}$ & $\begin{array}{l}\text { Williams, Robert John. Pennyland and Hartigans: Two Iron Age and } \\
\text { Saxon sites in Milton Keynes. Buckinghamshire Archaeological Society } \\
\text { monograph 4. Aylesbury: Buckinghamshire Archaeological Society, } \\
1993 .\end{array}$ \\
\hline $\begin{array}{l}\text { Pitstone, } \\
\text { Buckinghamshire }\end{array}$ & $\begin{array}{l}\text { PHILlips, Mark. «Excavation of an Early Saxon settlement at Pitstone». } \\
\text { Records of Buckinghamshire, 2005, 45, p. 1-32. }\end{array}$ \\
\hline
\end{tabular}




\begin{tabular}{|c|c|}
\hline $\begin{array}{l}\text { Settlements of study } \\
\text { (alphabetical) }\end{array}$ & References (select) \\
\hline $\begin{array}{l}\text { Poundbury, } \\
\text { Dorset }\end{array}$ & $\begin{array}{l}\text { GreEN, Christopher Sparey. Excavations at Poundbury volume I: } \\
\text { The settlements. Dorset Natural History and Archaeological Society } \\
\text { monograph } 7 \text {. Dorchester: Dorset Natural History and Archaeological } \\
\text { Society, } 1987 \text {. }\end{array}$ \\
\hline $\begin{array}{l}\text { Quarrington, } \\
\text { Lincolnshire }\end{array}$ & $\begin{array}{l}\text { TAYLOR, Gary. "An Early to Middle Saxon settlement at Quarrington, } \\
\text { Lincolnshire». The Antiquaries Journal, 2003, 83, p. 231-280. }\end{array}$ \\
\hline $\begin{array}{l}\text { Radley Barrow Hills, } \\
\text { Oxfordshire (formally } \\
\text { Berkshire) }\end{array}$ & $\begin{array}{l}\text { CHAMBERs, Richard \& McADAM, Ellen. Excavations at Barrow Hills, } \\
\text { Radley, Oxfordshire, 1983-5. Volume 2: The Romano-British cemetery and } \\
\text { Anglo-Saxon settlement. Oxford: Oxford Archaeology, Thames Valley } \\
\text { Landscapes monograph 25, } 2007 \text {. }\end{array}$ \\
\hline $\begin{array}{l}\text { Raunds Furnells, } \\
\text { Northamptonshire }\end{array}$ & $\begin{array}{l}\text { Audouy, Michel \& Chapman, Andy (eds.). Raunds: The origin and } \\
\text { growth of a midland village AD450-1500. Excavations in north Raunds, } \\
\text { Northamptonshire 1977-87. Oxford: Oxbow Books, 2009. }\end{array}$ \\
\hline $\begin{array}{l}\text { Riby Cross Roads, } \\
\text { Lincolnshire }\end{array}$ & $\begin{array}{l}\text { StEEDMAN, Ken. «Excavation of a Saxon site at Riby Cross Roads, } \\
\text { Lincolnshire». Archaeological Journal, 1994, 151, p. 212-306. }\end{array}$ \\
\hline $\begin{array}{l}\text { Riverdene, Basingstoke, } \\
\text { Hampshire }\end{array}$ & $\begin{array}{l}\text { Hall-Torrance, Melanie \& Weaver, Steven D. G. «The excavations } \\
\text { of a Saxon settlement at Riverdene, Basingstoke, Hampshire, 1995". } \\
\text { Proceedings of the Hampshire Field Club Archaeological Society, 2003, 58, } \\
\text { p. 63-105. }\end{array}$ \\
\hline $\begin{array}{l}\text { Simy Folds, } \\
\text { Upper Teesdale, Co. } \\
\text { Durham }\end{array}$ & $\begin{array}{l}\text { CogGins, Denis; FaIRnEss, Kenneth J. \& Batey, Coleen E. «Simy Folds: } \\
\text { An early medieval settlement site in Upper Teesdale, Co. Durham». } \\
\text { Medieval Archaeology, 1983, 27, p. 1-26. } \\
\text { CogGins, Denis. "Simy Folds: Twenty years on». In: Hines, John; } \\
\text { LANE, Alan \& ReDKnap, Mark (eds.). Land, sea and home: Proceedings } \\
\text { of a conference on Viking-period Settlement, at Cardiff, July 2001. Leeds: } \\
\text { Maney Publishing, 2004, p. 325-334. }\end{array}$ \\
\hline $\begin{array}{l}\text { Spong Hill, North } \\
\text { Elmham, } \\
\text { Norfolk }\end{array}$ & $\begin{array}{l}\text { RickETT, Robert. Spong Hill, part VII: The Iron Age, Roman and Early } \\
\text { Saxon settlement. East Anglian Archaeology } 73 \text {. Field Archaeology } \\
\text { Divisions: Norfolk Museums Service, } 1995 .\end{array}$ \\
\hline $\begin{array}{l}\text { Springfield Lyons, } \\
\text { Essex }\end{array}$ & $\begin{array}{l}\text { Tyler, Sue \& Major, Hilary. The Early Anglo-Saxon cemetery and later } \\
\text { Saxon settlement at Springfield Lyons, Essex. East Anglian Archaeology } \\
\text { 111. Chelmsford: Essex County Council, 2005. }\end{array}$ \\
\hline $\begin{array}{l}\text { Staunch Meadow } \\
\text { (Brandon), } \\
\text { Suffolk }\end{array}$ & $\begin{array}{l}\text { CARr, Robert D.; TeSter, Andrew \& Murphy, P. «The Middle-Saxon } \\
\text { settlement at Staunch Meadow, Brandon». Antiquity, 1988, 62/235, p. } \\
371-377 \text {. } \\
\text { TeSTER, Andrew; ANDERSON, Sue; RidDler, Ian \& CARR, Robert. } \\
\text { Staunch Meadow, Brandon, Suffolk: A high status Middle Saxon settlement } \\
\text { on the fen edge. East Anglian Archaeology 151. Bury St Edmonds: } \\
\text { Suffolk County Council Archaeological Service, 2014. }\end{array}$ \\
\hline
\end{tabular}




\begin{tabular}{|c|c|}
\hline $\begin{array}{l}\text { Settlements of study } \\
\text { (alphabetical) }\end{array}$ & References (select) \\
\hline $\begin{array}{l}\text { Sutton Courtenay/ } \\
\text { Drayton, } \\
\text { Oxfordshire (formally } \\
\text { Berkshire) }\end{array}$ & $\begin{array}{l}\text { LeEds, E. T. "A Saxon village near Sutton Courtenay, Berkshire». } \\
\text { Archaeologia, 1923, 73, p. 147-192. } \\
\text { LeEDS, E. T. "A Saxon village at Sutton Courtenay, Berkshire (second } \\
\text { Report)». Archaeologia, 1927, 76, p. 59-80. } \\
\text { LeEDS, E. T. "A Saxon village at Sutton Courtenay, Berkshire (third } \\
\text { Report)». Archaeologia, 1947, 92, p. 79-93. } \\
\text { HAMEROw, Helena; HaYDEN, Chris \& HEY, Gill. "Anglo-Saxon and } \\
\text { earlier settlement near Drayton Road, Sutton Courtenay, Berkshire». } \\
\text { Archaeological Journal, 2007, 164, p. 109-196. }\end{array}$ \\
\hline $\begin{array}{l}\text { Thirlings, } \\
\text { Northumberland }\end{array}$ & $\begin{array}{l}\text { O’Brien, Colm \& Miket, Roger. «The early medieval settlement of } \\
\text { Thirlings, Northumberland». Durham Archaeological Journal, 1991, } 7 \text {, } \\
\text { p. 57-91. }\end{array}$ \\
\hline $\begin{array}{l}\text { West Cotton, Raunds, } \\
\text { Northamptonshire }\end{array}$ & $\begin{array}{l}\text { Chapman, Andy. West Cotton, Raunds. A study of medieval settlement } \\
\text { dynamics AD450-1450: Excavation of a deserted medieval hamlet in } \\
\text { Northamptonshire, 1985-89. Oxford: Oxbow Books, } 2010 \text {. }\end{array}$ \\
\hline $\begin{array}{l}\text { West Fen Road, Ely, } \\
\text { Cambridgeshire }\end{array}$ & $\begin{array}{l}\text { Mortimer, Richard; Regan, Roderick \& LuCy, Sam. The Saxon and } \\
\text { medieval settlement at West Fen Road, Ely: The Ashwell site. East Anglian } \\
\text { Archaeology 110. Cambridge: Cambridge Archaeological Unit, } 2005 . \\
\text { MudD, Andrew \& Webster, Michael. Iron Age and Middle Saxon } \\
\text { settlements at West Fen Road, Ely, Cambridgeshire: The Consortium site. } \\
\text { BAR British Series 538. Oxford: Archaeopress \& Northamptonshire } \\
\text { Archaeology, 2011. }\end{array}$ \\
\hline $\begin{array}{l}\text { West Stow, } \\
\text { Suffolk }\end{array}$ & $\begin{array}{l}\text { West, Stanley. West Stow: The Anglo-Saxon village. Volume I: The text. } \\
\text { East Anglian Archaeology 24. Ipswich: Suffolk County Planning } \\
\text { Department, } 1985 \text {. } \\
\text { WEST, Stanley. West Stow: The Anglo-Saxon village. Volume II: The } \\
\text { fgures. East Anglian Archaeology 24. Ipswich: Suffolk County Planning } \\
\text { Department, } 1985 \text {. }\end{array}$ \\
\hline $\begin{array}{l}\text { Yarnton, } \\
\text { Oxfordshire }\end{array}$ & $\begin{array}{l}\text { Hey, Gill. Yarnton: Saxon and medieval settlement and landscape. Results } \\
\text { of excavations 1990-96. Thames Valley Landscapes monograph } 20 . \\
\text { Oxford: Oxford Archaeological Unit, 2004. }\end{array}$ \\
\hline
\end{tabular}

\section{REFERENCES}

Addyman, Peter V. «The Anglo-Saxon house: A new review». Anglo-Saxon England, 1972, 1, p. 273-307.

Anderton, Mike (ed.). Anglo-Saxon trading centres: Beyond the emporia. Glasgow: Cruithne Press, 1999.

Audouy, Michel \& Chapman, Andy (eds.). Raunds: The origin and growth of a midland village AD450-1500. Excavations in north Raunds, Northamptonshire 1977-87. Oxford: Oxbow Books, 2009.

Beresford, Guy. Goltho: The development of an early medieval manor c. 850-1150. London: Historic Buildings and Monuments Commission for England, 1987. 
BlaIr, John. Building Anglo-Saxon England. Princeton: Princeton University Press, 2018.

BlaIr, John. The church in Anglo-Saxon society. Oxford: Oxford University Press, 2005.

Brennan, Naomi \& Hamerow, Helena. "An Anglo-Saxon great hall complex at Sutton Courtenay/Drayton, Oxfordshire: A royal centre of early Wessex?». Archaeological Journal, 2015, 172 , p. 325-350.

Brookes, Stuart. Economics and social change in Anglo-Saxon Kent AD400-900: Landscapes, communities and exchange. BAR British Series 431. Oxford: BAR Publishing, 2007.

Chapman, Andy. West Cotton, Raunds. A study of medieval settlement dynamics AD450-1450: Excavation of a deserted medieval hamlet in Northamptonshire, 1985-89. Oxford: Oxbow Books, 2010.

Clegg Hyer, Maren \& Owen-Crocker, Gale R. (eds.). The material culture of daily living in the Anglo-Saxon world. Exeter: University of Exeter Press, 2011.

Cramp, Rosemary J. «Beowulf and Archaeology». Medieval Archaeology, 1957, 1, p. 57-77.

Dyer, Christopher \& Lilley, Keith. «Town and countryside: Relationships and resemblances». In: Christie, Neil \& Stamper, Paul (eds.). Medieval rural settlement: Britain and Ireland, AD800-1600. Bollington: Windgather, 2011, p. 81-98.

Evans, D. H. \& Loveluck, Christopher (eds.). Life and economy at early medieval Flixborough $c$. AD600-1000. Excavations at Flixborough Volume 2. Oxford: Oxbow Books, 2009.

Gardiner, Mark. "Late Saxon settlements». In: Hamerow, Helena; Hinton, David \& Crawford, Sally (eds.). The Oxford handbook of Anglo-Saxon archaeology. Oxford: Oxford University Press, 2011, p. 198-217.

Gardiner, Mark. «Manorial farmsteads and the expression of lordship before and after the Norman Conquest». In: Hadley, Dawn M. \& Dyer, Christopher (eds.). The archaeology of the $11^{\text {th }}$ century: Continuities and transformations. Society for Medieval Archaeology monograph 38. London: Routledge, 2017, p. 88-103.

Gerrard, Christopher. Medieval archaeology: Understanding traditions and contemporary approaches. London; New York: Routledge, 2003.

Hamerow, Helena. «Anglo-Saxon timber buildings and their social context». In: Hamerow, Helena; Hinton, David \& Crawford, Sally (eds.). The Oxford handbook of Anglo-Saxon archaeology. Oxford: Oxford University Press, 2011, p. 128-155.

Hamerow, Helena. Early medieval settlements: The archaeology of rural communities in North-West Europe 400-900. Oxford: Oxford University Press, 2002.

Hamerow, Helena. Rural settlements and society in Anglo-Saxon England. Oxford: Oxford University Press, 2012.

Hamerow, Helena; Hayden, Chris \& Hey, Gill. «Anglo-Saxon and earlier settlement near Drayton Road, Sutton Courtenay, Berkshire». Archaeological Journal, 2007, 164, p. 109-196.

Hansen, Inge Lyse \& Wiскнам, Christopher (eds.). The long eighth century: Production, distribution and demand. Leiden: Brill, 2000.

Hill, John M. The cultural world in Beowulf. Toronto: University of Toronto Press, 1995.

Hinton, David A. "The fifth and sixth centuries: Reorganisation among the ruins». In: Karkov, Catherine E. (ed.). The archaeology of Anglo-Saxon England: Basic readings. New York: Garland Publishing Inc., 1999, p. 53-78.

Hinton, David A. Gold and gilt, pots and pins: Possessions and people in medieval Britain. Oxford: Oxford University Press, 2005.

Hodges, Richard. Dark Age economics: A new audit. London: Bloomsbury Academic, an imprint of Bloomsbury Publishing Plc., 2013. 
Hоoкe, Della. The landscape of Anglo-Saxon England. London; Washington: Leicester University Press, 1998.

Hope-Taylor, Brian. Yeavering: An Anglo-British centre of early Northumbria. Swindon: H. M. Stationery Office, 1977.

Jones, Richard \& Page, Mark. Medieval villages in an English landscape: Beginnings and ends. Cheshire: Windgather Press, 2006.

LewIs, Hana. Pattern and process in the material culture of Anglo-Saxon non-elite rural settlements. UCL Institute of Archaeology PhD Series 1. Oxford: BAR Publishing, 2019.

Loveluck, Christopher \& Tys, Dries. «Coastal societies, exchange, and identity along the channel and the North Sea shores of Europe, AD600-1000». Journal of Marine Archaeology, 2006, 1, p. 140-169.

Loveluck, Christopher. «Central-places, exchange and maritime-oriented identity around the North Sea and western Baltic, AD600-1100». In: Gelichi, Sauro \& Hodges, Richard (eds.). From one sea to another: Trading places in the European and Mediterranean early Middle Ages. Proceedings of the International Conference Comacchio, 27 th $-29^{\text {th }}$ March 2009. Turnhout: Brepols, 2012, p. 123-165.

Loveluck, Christopher. "Wealth, waste and conspicuous consumption: Flixborough and its importance for Middle and Late Saxon rural settlement studies». In: Hamerow, Helena \& MacGregor, Arthur (eds.). Image and power in the archaeology of early medieval Britain: Essays in honour of Rosemary Cramp. Oxford: Oxbow Books, 2001, p. 78-130.

Loveluck, Christopher. Northwest Europe in the early Middle Ages, c. AD600-1150: A comparative archaeology. Cambridge: Cambridge University Press, 2013.

Loveluck, Christopher. Rural settlement, lifestyles and social change in the later first millennium AD: Anglo-Saxon Flixborough in its wider context. Excavations at Flixborough Volume 4. Oxford: Oxbow Books, 2007.

Lowry, Scott. Ritual and politics: Power negotiations at Anglo-Saxon feasts. Unpublished PhD thesis, University of North Carolina, 2003.

Marshall, Anne \& Marshall, Garry. "A survey and analysis of the buildings of Early and Middle Anglo-Saxon England». Medieval Archaeology, 1991, 35, p. 29-43.

Marshall, Anne \& Marshall, Garry. «Differentiation, change and continuity in Anglo-Saxon buildings". Archaeological Journal, 1993, 150, p. 366-402.

McCormick, Michael. Origins of the European economy: Communications and commerce AD300900. Cambridge: Cambridge University Press, 2002.

Millett, Martin \& James, Simon. «Excavations at Cowdery's Down, Basingstoke, Hampshire, 1978-81». Archaeological Journal, 1983, 140, p. 151-279.

Molyneaux, George. The formation of the English kingdom in the tenth century. Oxford: Oxford University Press, 2015.

Moreland, John F. «The significance of production in eighth century England». In: Hansen, Inge Lise \& Wiскнам, Christopher (eds.). The long eighth century: Production, distribution and demand. Leiden: Brill, 2000, p. 69-104.

Orton, Clive. Sampling in archaeology. Cambridge: Cambridge University Press, 2000.

Palmer, Ben. «The hinterlands of three southern English emporia: Some common themes». In: Pestell, Tim \& Ulmschneider, Katharina (eds.). Markets in early medieval Europe: Trading and "productive» sites, 650-850. Macclesfield: Windgather Press, 2003, p. 48-60.

Powlesland, Dominic. «Early Anglo-Saxon settlements, structures, form and layout». In: Hines, John (ed.). The Anglo-Saxons from the migration period to the eighth century: An ethnographic perspective. Woodbridge: Boydell Press, 1997, p. 101-124. 
Radford, C. A. Ralegh. «The Saxon house: A review and some parallels». Medieval Archaeology, 1957, 1, p. 27-38.

Rahtz, Philip A. «Buildings and rural settlements». In: Wilson, David Mackenzie (ed.). The archaeology of Anglo-Saxon England. Cambridge: Cambridge University Press, 1976, p. 49-98.

REYNOLDS, Andrew. "Boundaries and settlements in later $6^{\text {th }}$ to $11^{\text {th }}$ century England». In: Griffiths, David W.; Reynolds, Andrew \& Semple, Sarah (eds.). Boundaries in early medieval Britain. Anglo-Saxon Studies in Archaeology and History 12. Oxford: Oxford University School of Archaeology, 2003, p. 97-139.

Reynolds, Andrew. Later Anglo-Saxon England: Life and landscape. Stroud: Tempus, 1999.

Richards, Julian D. "What's so special about 'productive sites'? Middle Saxon settlements in Northumbria». In: Dickinson, Tania M. \& Griffiths, David W. (eds.). The making of kingdoms: Papers from the 47th Sachsen symposium, York, September 1996. Anglo-Saxon studies in archaeology and history 10. Oxford: Oxford University Committee for Archaeology, 1999, p. 71-80.

Rippon, Stephen. «Landscape change during the «long eighth century» in southern England». In: Higham, Nicholas J. \& Ryan, Martin J. (eds.). The landscape archaeology of Anglo-Saxon England. Woodbridge: Boydell Press, 2010, p. 39-64.

Rippon, Stephen. Making sense of an historic landscape. Oxford: Oxford University Press, 2012.

Rogerson, Andrew. A Late Neolithic, Saxon and medieval site at Middle Harling, Norfolk. East Anglian Archaeology 74. London: British Museum; Norfolk: Field Archaeology Division, Norfolk Museums Service, 1995.

Rowland, Jenny. «OE Ealuscerwen/Meoduscerwen and the concept of 'paying for mead'». Leeds Studies in English, 1990, 21, p. 1-12.

Schiffer, Michael B. «Toward the identification of formation processes». American Antiquity, 1983, 48, p. 675-706.

SCHIfFer, Michael B. Formation processes of the archaeological record. Albuquerque: University of New Mexico Press, 1987.

Scull, Christopher. «Social transactions, gift exchange, and power in the archaeology of the fifth to seventh centuries». In: Hamerow, Helena; Hinton, David A. \& Crawford, Sally (eds.). The Oxford handbook of Anglo-Saxon archaeology. Oxford: Oxford University Press, 2011, p. 848-864.

Tester, Andrew; Anderson, Sue; Riddler, Ian \& Carr, Robert. Staunch Meadow, Brandon, Suffolk: A high status Middle Saxon settlement on the fen edge. East Anglian Archaeology 151. Bury St Edmonds: Suffolk County Council Archaeological Service, 2014.

Tipper, Jess. The grubenhaus in Anglo-Saxon England: An analysis and interpretation of the evidence from a most distinctive building type. Yedingham, North Yorkshire: Landscape Research Centre, 2004.

Ulmschneider, Katharina. «Central places and metal-detector finds: What are the English 'productive sites'?» In: HÅRDT, Birgitta \& Larsson, Lars (eds.). Central places in the Migration and Merovingian periods: Papers from the 52 $2^{\text {nd }}$ Sachsensymposium, Lund. Stockholm: Almqvist \& Wiksell International, 2002, p. 333-339.

Ulmschneider, Katharina. "Settlement hierarchy». In: Hamerow, Helena; Hinton, David \& Crawford, Sally (eds.). The Oxford handbook of Anglo-Saxon archaeology. Oxford: Oxford University Press, 2011, p. 156-171.

Wicкham, Christopher. Framing the early Middle Ages: Europe and the Mediterranean, 400-800. Oxford: Oxford University Press, 2005.

Wright, Duncan W. 'Middle Saxon'settlement and society. Oxford: Archaeopress, 2015. 